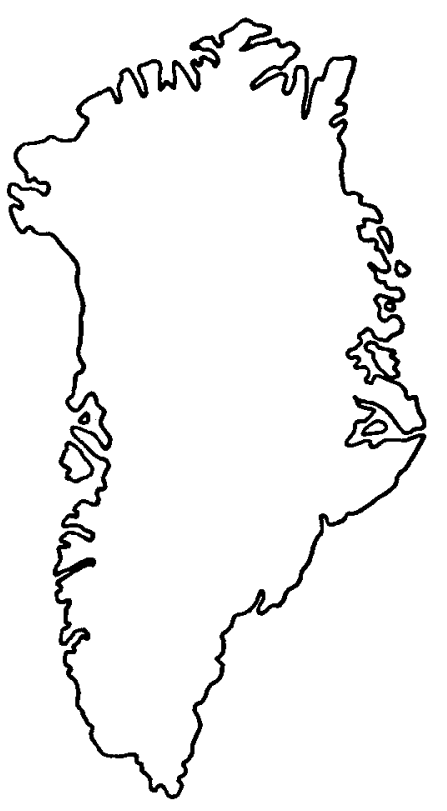

\title{
The Wandel Valley Formation (Early - Middle Ordovician) of North Greenland and its correlatives
}

\author{
John S. Peel and M. Paul Smith
}

\begin{abstract}
Members are formally described within the Wandel Valley Formation (Early - Middle Ordovician) of the Ryder Gletscher Group in central and eastern North Greenland. In Peary Land the names Pyramideplateau Member (the combined lower and middle informal members of previous usage) and Vestervig Elv Member (the upper member) are proposed. In Kronprins Christian Land, the Alexandrine Bjerge Member (new) overlies the previously named Danmarks Fjord and Amdrup Members. Conodont studies, supported by the macrofauna, indicate that the Pyramideplateau, Danmarks Fjord and Amdrup Members are of late Canadian (Early Ordovician) age. The Canadian-Whiterockian boundary lies within the lowermost part of the Vestervig Elv and Alexandrine Bjerge Members. The top of the former is of earliest Late Whiterockian age while the Alexandrine Bjerge Member only extends into the late Middle Whiterockian. The members of the Wandel Valley Formation are correlated with coeval successions in western North Greenland, East Greenland, the Canadian Arctic Islands and Svalbard.
\end{abstract}

J. S. P., Grønlands Geologiske Unders $\varnothing$ gelse, Øster Voldgade 10, DK-1350 København K, Danmark.

M. P. S., Department of Earth Sciences, University of Cambridge, Downing Street, Cambridge CB2 3EQ, U, K.

Although Lauge Koch (1923) briefly described Lower Palaeozoic strata in southern Peary Land, it was Johannes C. Troelsen (1949) who first introduced formal stratigraphic names for the Cambrian-Ordovician carbonate sequence overlying Cambrian siliciclastic sediments (subsequently referred to the Buen Formation by Jepsen, 1971) around the mouth of Børglum Elv and along the northern side of Jørgen Brønlund Fjord (figs 1-3).

The Wandel Valley Limestone of Troelsen (1949) succeeded his Brønlund Fjord Dolomite and was overlain by a third carbonate unit for which he introduced the name Børglum River Limestone. Troelsen suggested a Cambrian age for the Brønlund Fjord Dolomite, an Early Ordovician age for the Wandel Valley Limestone and a Middle to Late Ordovician age for the Børglum River Limestone. His age assignment for the Wandel Valley Limestone was based on collections of specimens of the operculum of the characteristic Early Ordovician 

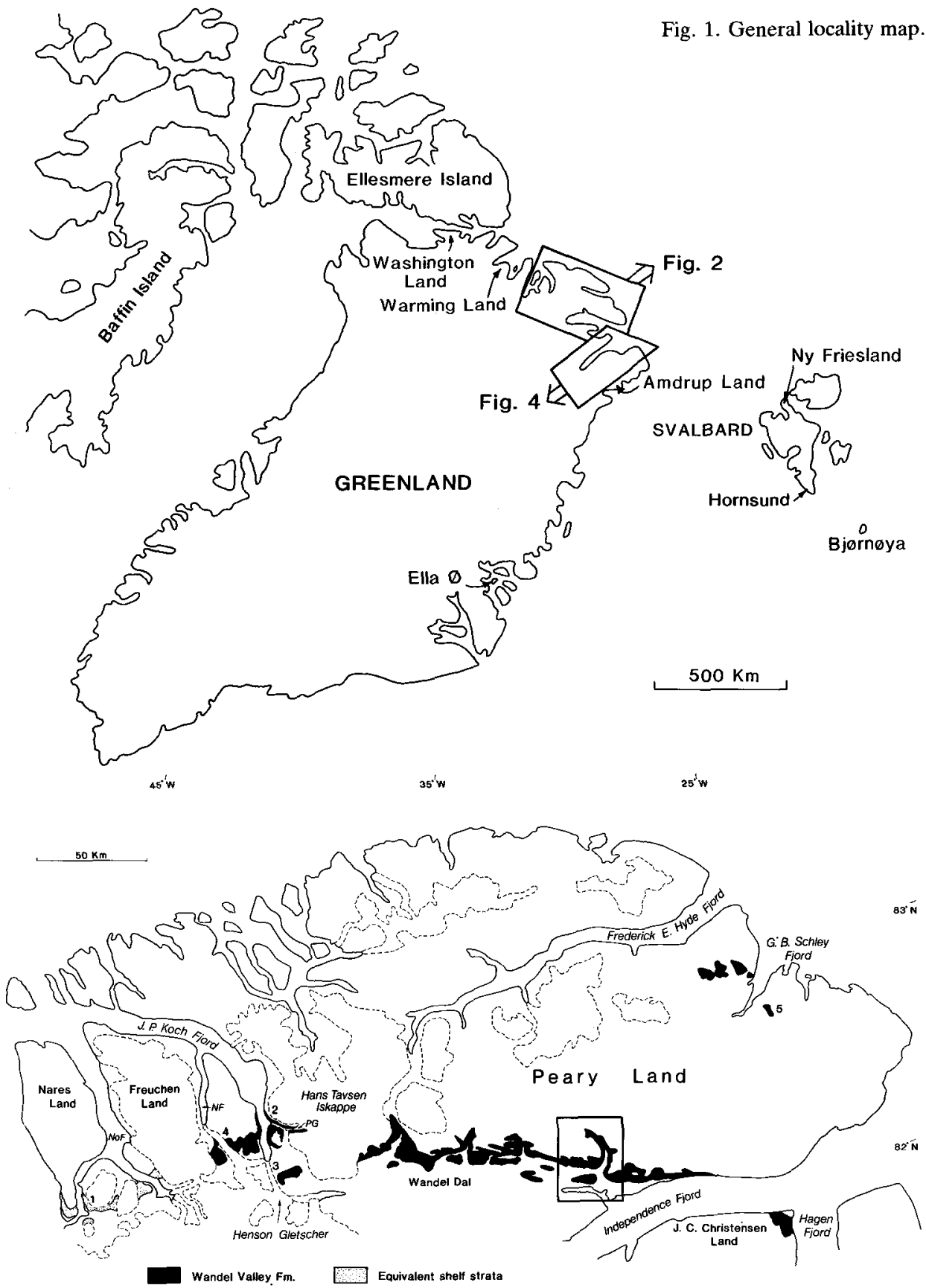

Fig. 2. Outcrop of the Wandel Valley Formation and equivalent shelf strata in the Nares Land - Peary Land region. Inset shows location of fig. 3. Numbers indicate location of photographic figures: 1, fig. 12; 2, fig. 10B; 3, figs 10A, C, D; 4, fig. 14; 5, fig. 15. NF, Navarana Fjord; NoF, Nordenskiöld Fjord; PG, Perssuaq Gletscher. 


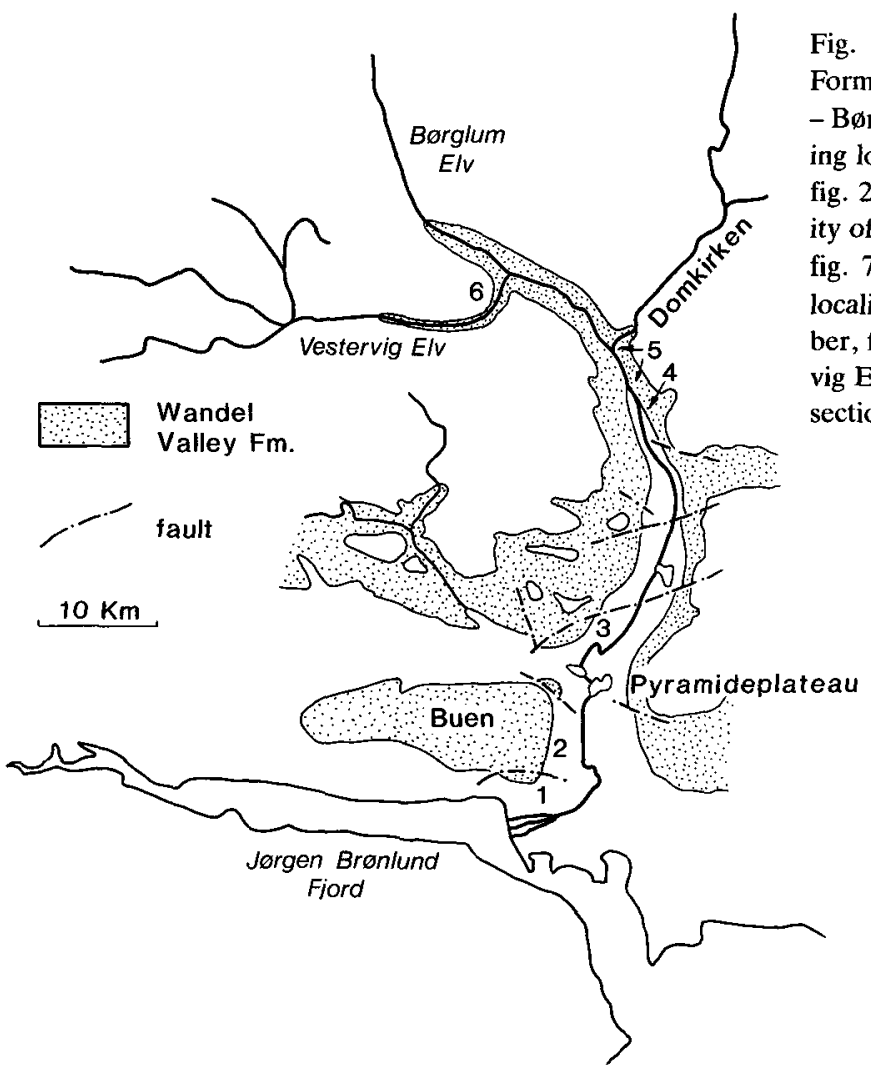

Fig. 3. Outcrop of the Wandel Valley Formation in the Jørgen Brønlund Fjord - Børglum Elv area of Peary Land showing localities mentioned in the text. See fig. 2 for general location. 1, type locality of the Wandel Valley Formation, see fig. 7 ; 2, fig. 13B; 3, fig. 13A; 4, type locality of the Pyramideplateau Member, fig. $8 ; 5$, type locality of the Vestervig Elv Member, see fig. 9; 6, reference section of the Vestervig Elv Member.

gastropod Ceratopea from the lower beds of the formation; the identification was subsequently confirmed by Yochelson \& Peel (1975) who described Troelsen's specimens of the genus from localities near the mouth of Børglum Elv.

Reviews and brief additional comments on Troelsen's original observations concerning the Wandel Valley Limestone have been given by various authors (e.g. Troelsen, 1956; Cowie, 1961; Haller, 1971). Cowie (1971) first introduced the term Wandel Valley Formation. However, it was not until R. L. Christie and J. S. Peel compiled stratigraphic logs along the valley of Børglum Elv in 1974 that substantial new field observations were made concerning the nature of the formation in southern Peary Land (Peel \& Christie, 1975). The formation was described in some detail by Christie \& Peel (1977) who also gave descriptions of measured sections near Domkirken in the valley of Børglum Elv (fig. 3). Three members (lower, middle and upper) were recognised but not formally described.

Subsequent field work in central North Greenland, principally undertaken as part of the North Greenland Project $(1978-80 ; 1984-85)$ organised by the Geological Survey of Greenland, has demonstrated that the division of the Wandel Valley Formation into three members is not satisfactory since a gradational relationship, varying from locality to locality, exists between the original lower and middle members. Thus, in the present paper, only two formal members are proposed within the Wandel Valley Formation of Peary Land. The Pyramideplateau Member includes the lower and middle members of Christie \& Peel (1977) 


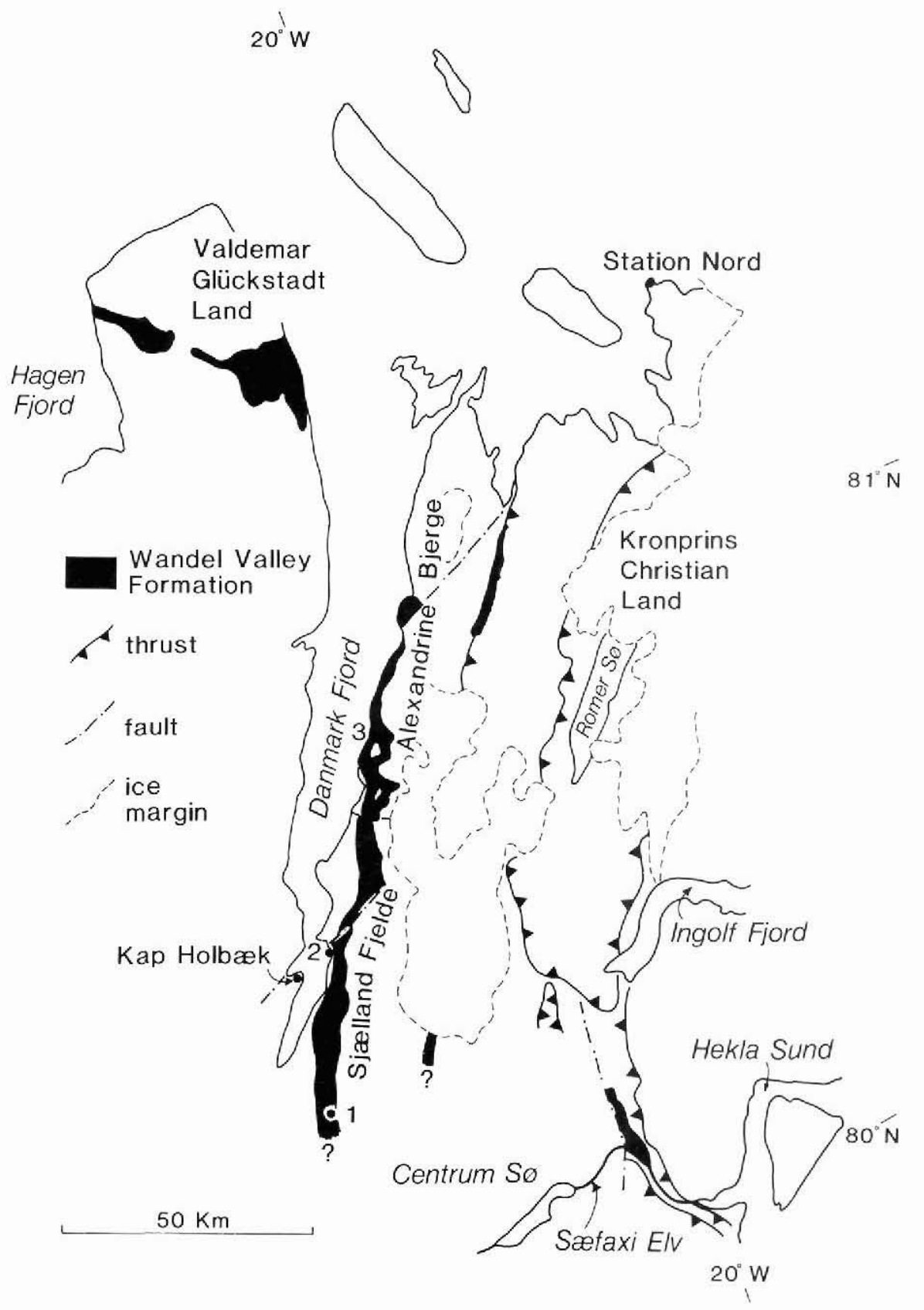

Fig. 4. Outcrop of the Wandel Valley Formation in the area around Danmark Fjord. For general location see fig. 2. The southward extension of outcrops from Sjælland Fjelde is not known. 1, reference section of the Amdrup Member described by Adams \& Cowie (1953); 2, reference section of the Amdrup Member and type locality of the Alexandrine Bjerge Member (see fig. 18B); 3, fig. 18A. 
while the overlying Vestervig Elv Member is exactly equivalent to the upper member of Christie \& Peel (1977).

Lower Palaeozoic strata in Kronprins Christian Land (fig. 4) traditionally have been addressed with a different stratigraphic nomenclature from that employed in Peary Land, although a single regional classification is now employed (see Peel, 1982, 1986 and Higgins et $a l$., in press, for summaries). While Adams \& Cowie (1953) recognised carbonates of Early Ordovician age within their embracive (and now abandoned) Centrum Limestone, the equivalence of these strata to units in Peary Land remained conjectural until Peel (1980a) recognised the presence of the Wandel Valley Formation in Kronprins Christian Land. Subsequent field work indicated that the Danmarks Fjord Dolomite of Fränkl (1955) and the Amdrup Formation of Cowie (1971) as restricted by Scrutton (1975) merely represented two lower members within the Wandel Valley Formation in Kronprins Christian Land (Peel et al., 1981; Peel, 1986; Smith \& Peel, 1986). An upper member remained un-named, howev$\mathrm{er}$, and it is for this unit that the name Alexandrine Bjerge Member is now introduced (fig. 5).

\section{Geological setting}

Lower Palaeozoic strata in northern Greenland were deposited in the eastward continuation of the Franklinian Basin of Arctic Canada (Higgins et al., in press). Ordovician strata forming part of the southern shelf sequence of the Franklinian Basin are assigned to the Ryder Gletscher Group (Early Cambrian - Middle Ordovician) of Peel \& Wright (1985) as redefined by Ineson \& Peel (1987) or to the succeeding Morris Bugt Group (Middle Ordovician - early Silurian) of Peel \& Hurst (1980) as redefined by Smith et al. (in press). Siliciclastic Ordovician strata are also present within outer slope and deep-water trough sequences exposed to the north of the shelf sequences (Higgins et al., in press).

The Ryder Gletscher Group is a sequence of carbonates of shallow-water, restricted platform aspect, associated with subordinate siliciclastic sediments and evaporites. Strata assigned to the group occur throughout North Greenland and many formations can be readily traced into Ellesmere Island and through the Canadian Arctic Islands (Peel \& Christie, 1982; Higgins et al., in press). Sediments of the Ryder Gletscher Group in Washington Land (fig. 1) extend from the Early Cambrian into the Middle Ordovician, but in more eastern areas a deeper-water, outer shelf sequence (Brønlund Fjord and Tavsens Iskappe Groups) generally precedes Ryder Gletscher Group strata. The outer shelf sequence is entirely of Early Cambrian age in Warming Land (fig. 1) but in eastern Freuchen Land and western Peary Land (fig. 2), the sequence extends through the Late Cambrian. In general, the outer shelf sequence in this area is unconformably overlain by Ryder Gletscher Group sediments of late Early to Middle Ordovician age which are referred to the Wandel Valley Formation. However, in the area around Henson Gletscher the outer shelf sequence of the Brønlund Fjord and Tavsens Iskappe Groups is conformably overlain by Ryder Gletscher Group sediments of the Koch Væg Formation (?middle Cambrian) which are themselves unconformably overlain by the Wandel Valley Formation (fig. 5).

On account of its basal unconformity the Wandel Valley Formation gradually oversteps underlying Cambrian formations toward the east to eventually overlie Proterozoic strata of the Kap Holbæk Formation in the area around Danmark Fjord (fig. 6). 


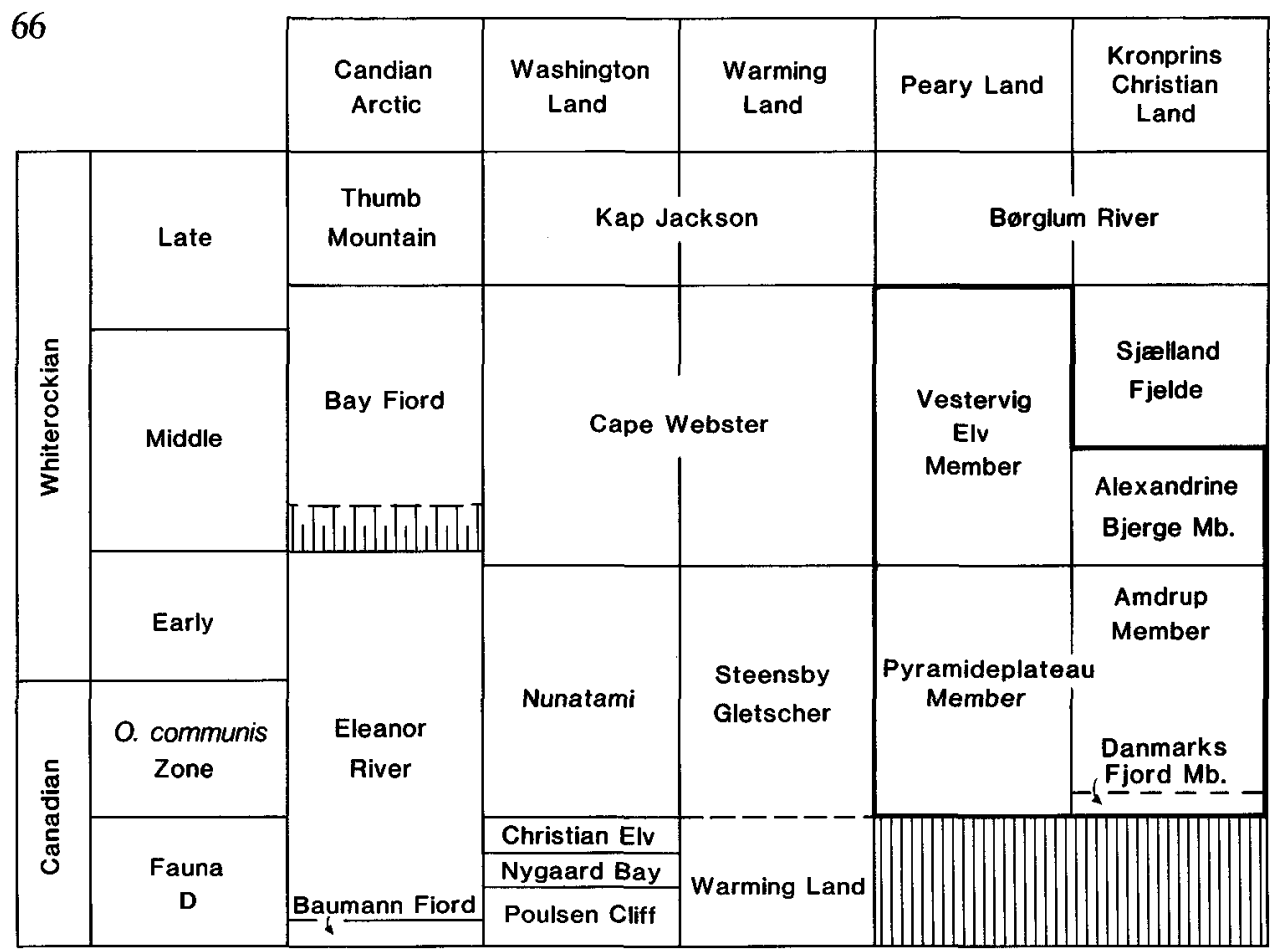

Ryder Gletscher Group sedimentation was terminated in the late Middle Ordovician with transgression and the establishment of a stable platform sequence (Morris Bugt and Washington Land Groups) which persisted into the early Silurian (Higgins et al., in press).

\section{Wandel Valley Formation}

Name. After Wandel Dal, the prominent valley extending westward from Jørgen Brønlund Fjord toward Henson Gletscher and forming the southern boundary of Peary Land (figs 1, 2).

History. The Wandel Valley Limestone of Troelsen (1949), referred to the Wandel Valley Formation by Peel \& Christie (1975) and more fully described in the valley of Børglum Elv, southern Peary Land, by Christie \& Peel (1977). The formation is now known to extend south-eastward into Kronprins Christian Land where it includes the Danmarks Fjord Dolomite of Fränkl (1955; see discussion, below) and the Amdrup Formation sensu Scrutton (1975; see review by Peel et al., 1981), both units originally parts of the now abandoned Centrum Limestone of Adams \& Cowie (1953).

Fig. 6. Stratigraphic relationships of the Wandel Valley Formation in the Peary Land - Kronprins Christian Land region. 


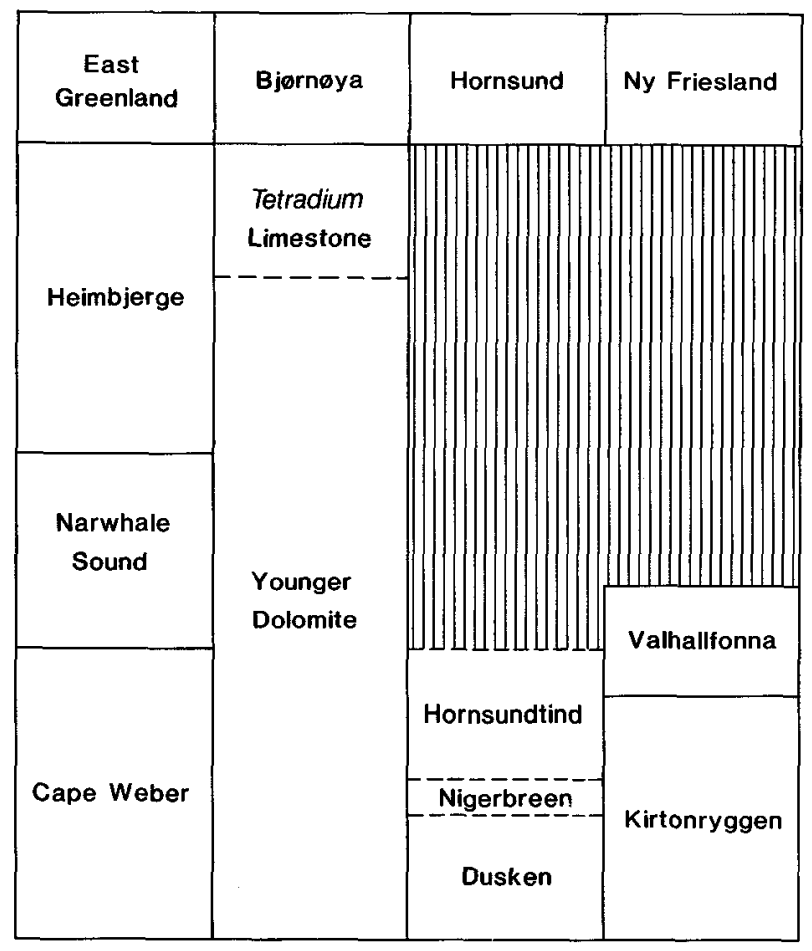

Fig. 5. Members of the Wandel Valley Formation (heavy border) and their correlation within the Canadian Arctic Archipelago, Svalbard and other areas of Greenland (fig. 1).

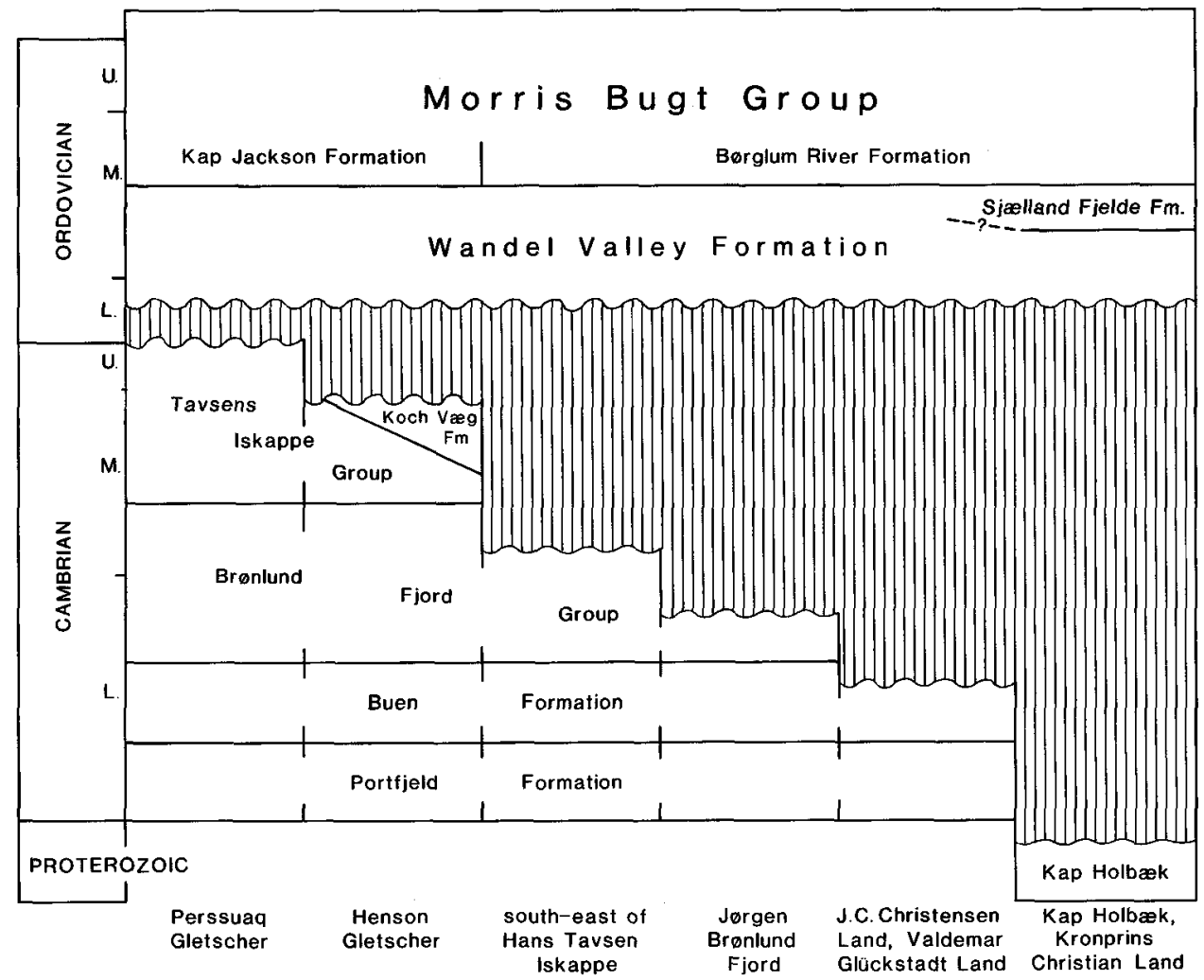


A

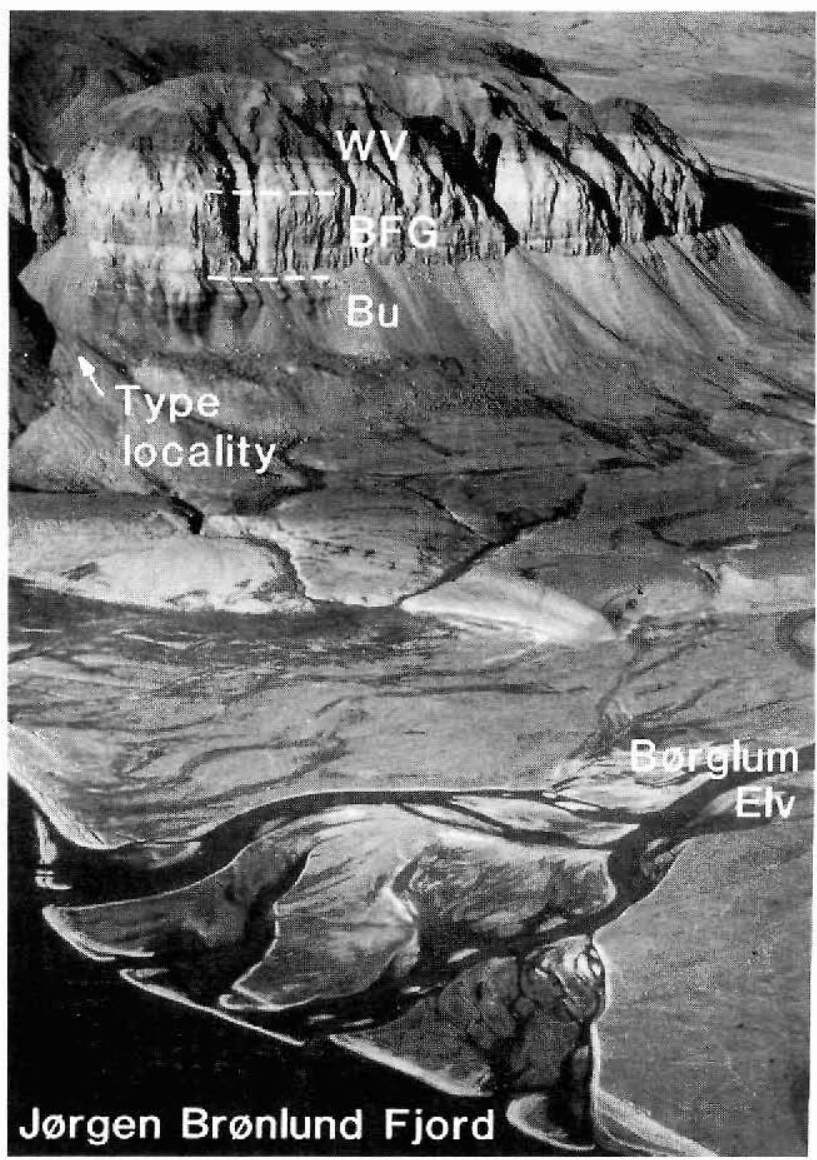

Fig. 7. A, Type locality of the Wandel Valley Formation at the mouth of Børglum Elv, Peary Land. Locality 1 in fig. 3. B, western margin of Pyramideplateau forming the eastern side of the valley of Børglum Elv. Bu, Buen Formation; BFG, Brønlund Fjord Group; WV, Wandel Valley Formation (photo: N. Henriksen).

B

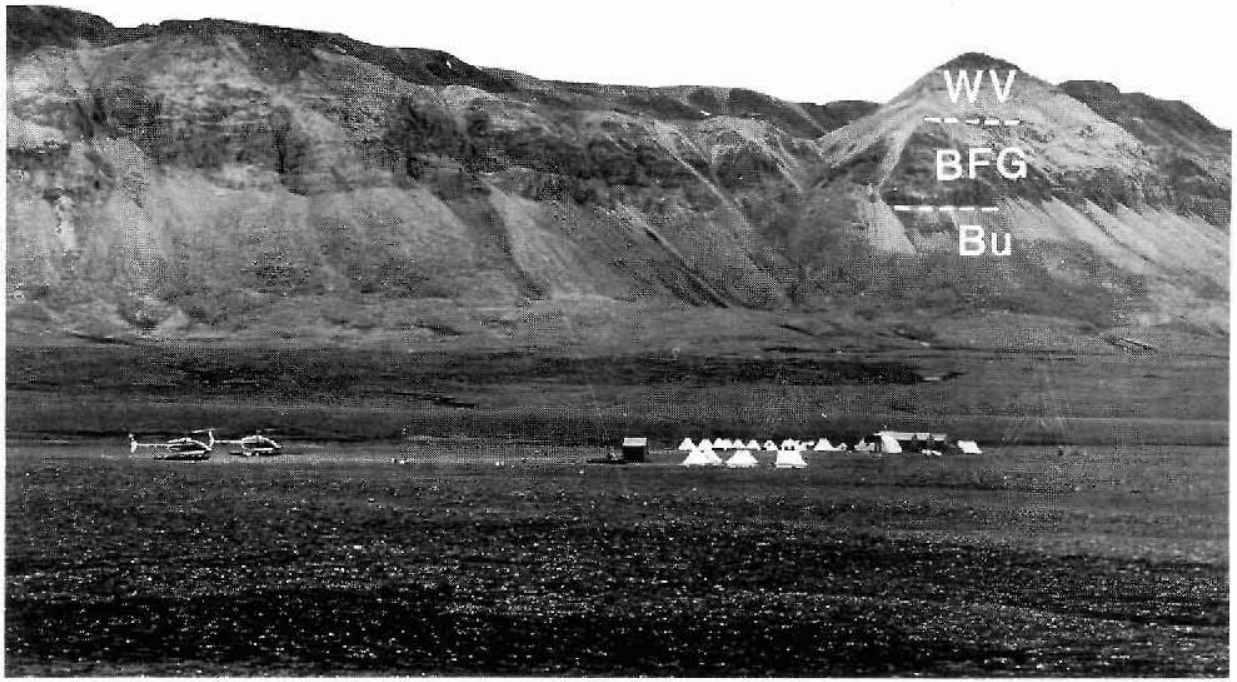




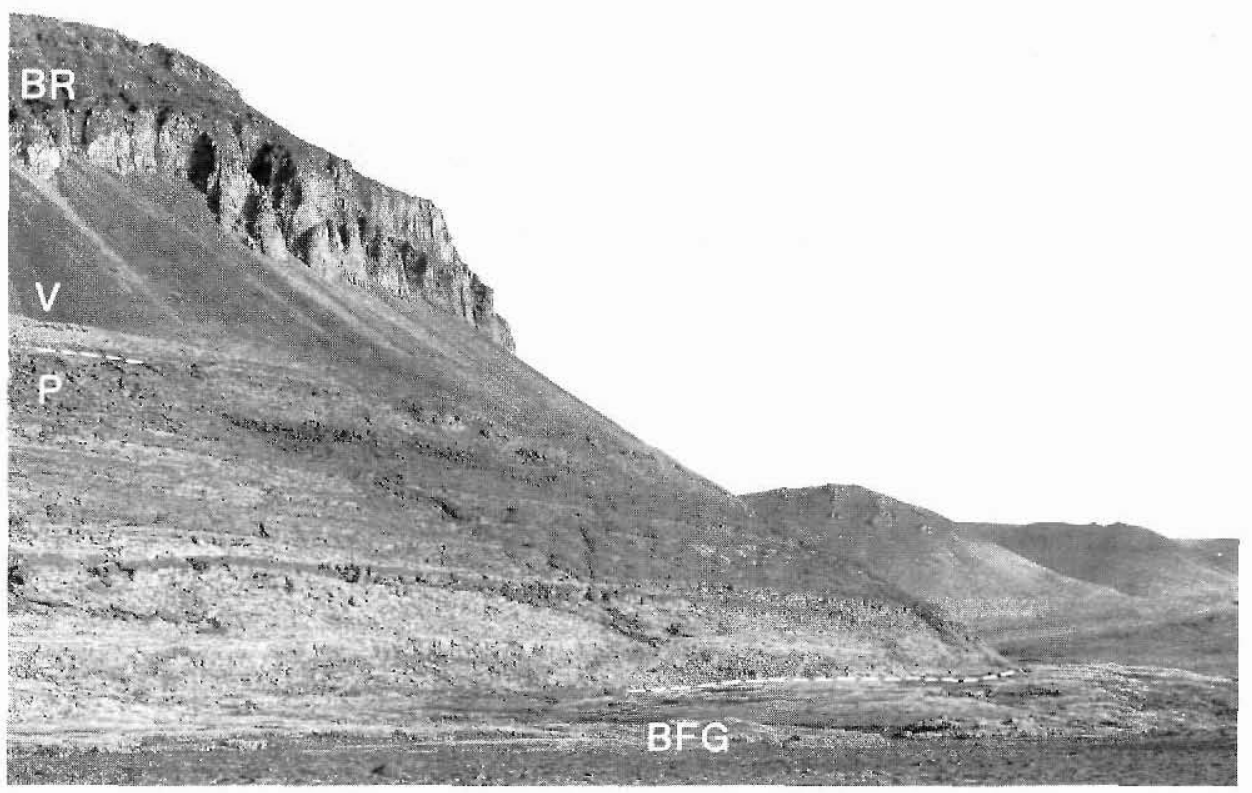

Fig. 8. Type locality for the Pyramideplateau Member and reference section for the Wandel Valley Formation, valley of Børglum Elv. Locality 4 in fig. 3. BR, Børglum River Formation of the Morris Bugt Group; V, Vestervig Elv Member; P, Pyramideplateau Member; BFG, Brønlund Fjord Group.

Type locality. Troelsen (1949, fig. 7) described the lower beds of the formation from a locality on the west side of the mouth of Børglum Elv, and this gully section in the south-eastern corner of the plateau Buen is considered to be the type locality (Troelsen, 1956; see figs 3, 7A). Troclsen remarked that only the lower $75 \mathrm{~m}$ of the formation are exposed at this locality, corresponding to the lower member and part of the middle member of Christie \& Peel (1977), both now grouped into the Pyramideplateau Member. However, higher beds of the Pyramideplateau Member and the basal beds of the overlying Vestervig Elv Member form cliff tops adjacent to Troelsen's locality (fig. 7A).

Reference section. The composite section measured by Christie \& Peel (1977) downstream of Domkirken (figs $3,8,9$ ). This is the type section for the two new members described from Peary Land.

Lithology. Finely crystalline, pale weathering, laminated to thin bedded, light to medium grey dolomites and dark weathering, dark grey-brown, burrow-mottled dolomites and limey dolomites characterise the lower part of the formation in both Peary Land (Pyramideplateau Member) and Kronprins Christian Land (Danmarks Fjord and Amdrup Members). Pale weathering, laminated to thin bedded, light to medium grey dolomites dominate the upper part of the formation (Vestervig Elv and Alexandrine Bjerg Members) in both areas. Chert nodules and thin beds of intraformational conglomerate occur in all members. 


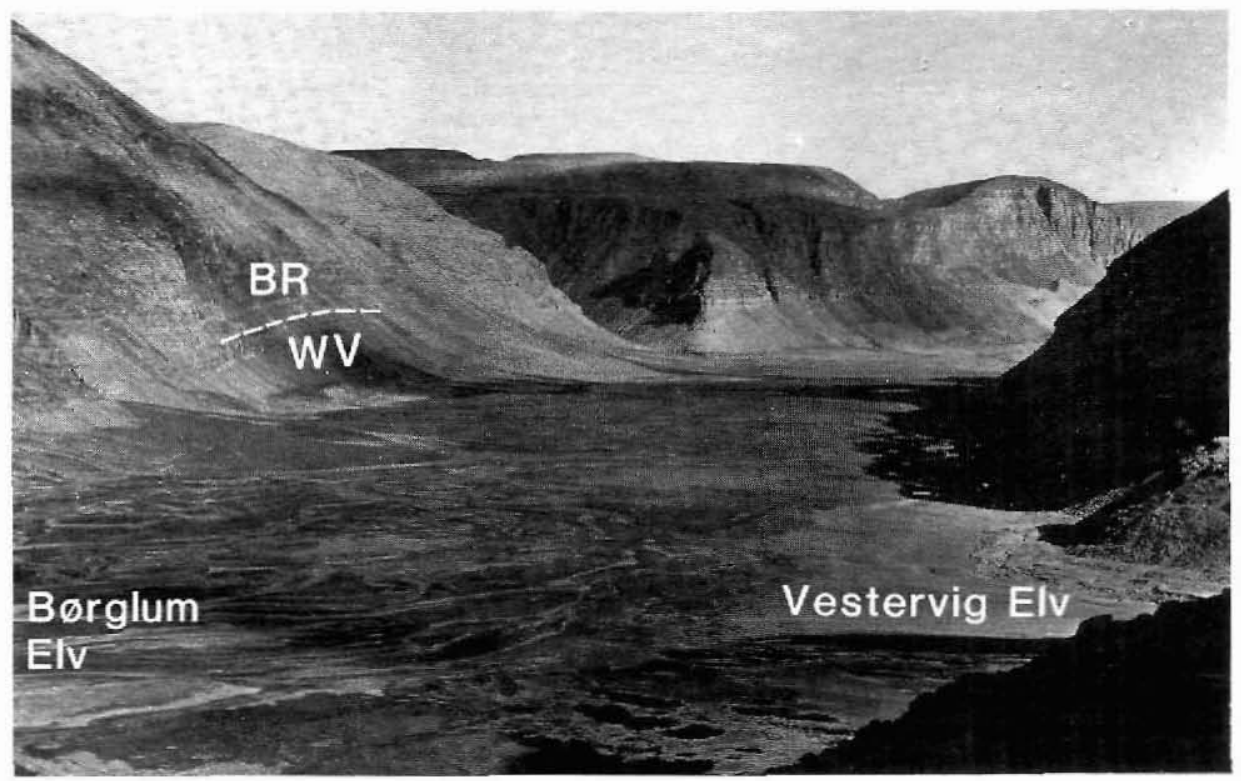

Fig. 9. View south-east from locality 6 in fig. 3 across the junction between Vestervig Elv and Børglum Elv toward the natural stone edifice which inspired the name Domkirken (the cathedral) for the gorge at its northern extremity. Cliff-forming limestone of the Børglum River Formation (BR) overlies generally recessive pale weathering dolomites of the Wandel Valley Formation (WV). The type locality of the Vestervig Elv Member (locality 5 in fig. 3) lies on the slopes below the Børglum Elv Formation just downstream (right) of the entrance to Domkirken.

Thickness. The formation is about $320 \mathrm{~m}$ thick at the reference locality. In Kronprins Christian Land and at J. P. Koch Fjord in western Peary Land approximately $400 \mathrm{~m}$ of strata are present.

Boundaries. The Wandel Valley Formation unconformably overlies older strata throughout its outcrop (fig. 6), although evidence of angular discordance is not commonly discernible in individual outcrops. In eastern Freuchen Land and western Peary Land, the formation generally overlies the Tavsens Iskappe Group (Middle - Late Cambrian, ?earliest Ordovician; see fig. 10B), although at Henson Gletscher the Wandel Valley Formation overlies the Koch Væg Formation of the Ryder Gletscher Group (Ineson \& Peel, 1987; see fig. 10A, C). It progressively oversteps these strata and the underlying Brønlund Fjord Group (Early Middle Cambrian) eastward across southern Peary Land toward Independence Fjord. In J. C. Christensen Land and Valdemar Glückstadt Land the Wandel Valley Formation has completely overstepped the Brønlund Fjord Group to lie directly on the Buen Formation of Early Cambrian age. At Kap Holbæk and in southern Kronprins Christian Land, the Wandel Valley Formation unconformably overlies the Kap Holbæk Formation of late Proterozoic age (Peel, 1986; see figs 6, 11A, B).

The Wandel Valley Formation is conformably overlain by the Børglum River Formation (Middle - Late Ordovician) of the Morris Bugt Group in its type area of southern Peary 

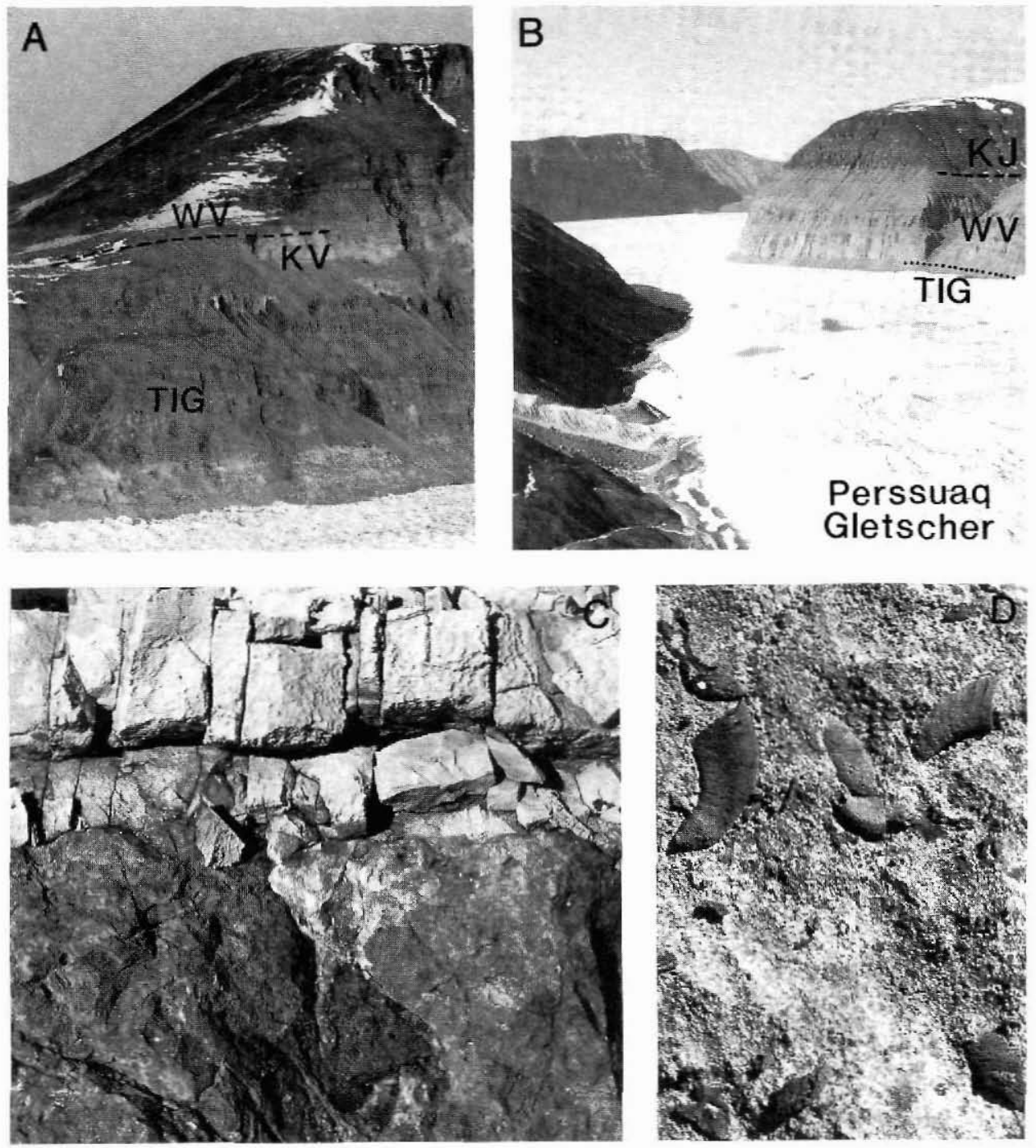

Fig. 10. The Wandel Valley Formation in westernmost Peary Land. A, Wandel Valley Formation (WV) overlying the Koch Vag Formation (KV) of the Ryder Gletscher Group and the Tavsens lskappe Group (TIG) on the eastern side of Henson Gletscher, locality 3 in fig. 2, height of cliff about $700 \mathrm{~m}$. B, View down Perssuaq Gletscher (fig. 2, locality 2) toward J. P. Koch Fjord. The Wandel Valley Formation (WV) in this section is about $400 \mathrm{~m}$ thick. KJ, Kap Jackson Formation; TIG, Tavsens Iskappe Group. C, contact between pale dolomite of the Wandel Valley Formation, Pyramideplateau Member, and darker breccia forming the top of the Koch Væg Formation. Height of exposure about $60 \mathrm{~cm}$. Henson Gletscher, see fig. 10A, locality 3 in fig. 2. D, silicified opercula of the gastropod Ceratopea on bedding surface of Pyramideplateau Member. About half natural size. Henson Gletscher, see fig. 10A, locality 3 in fig. 2 . 
A
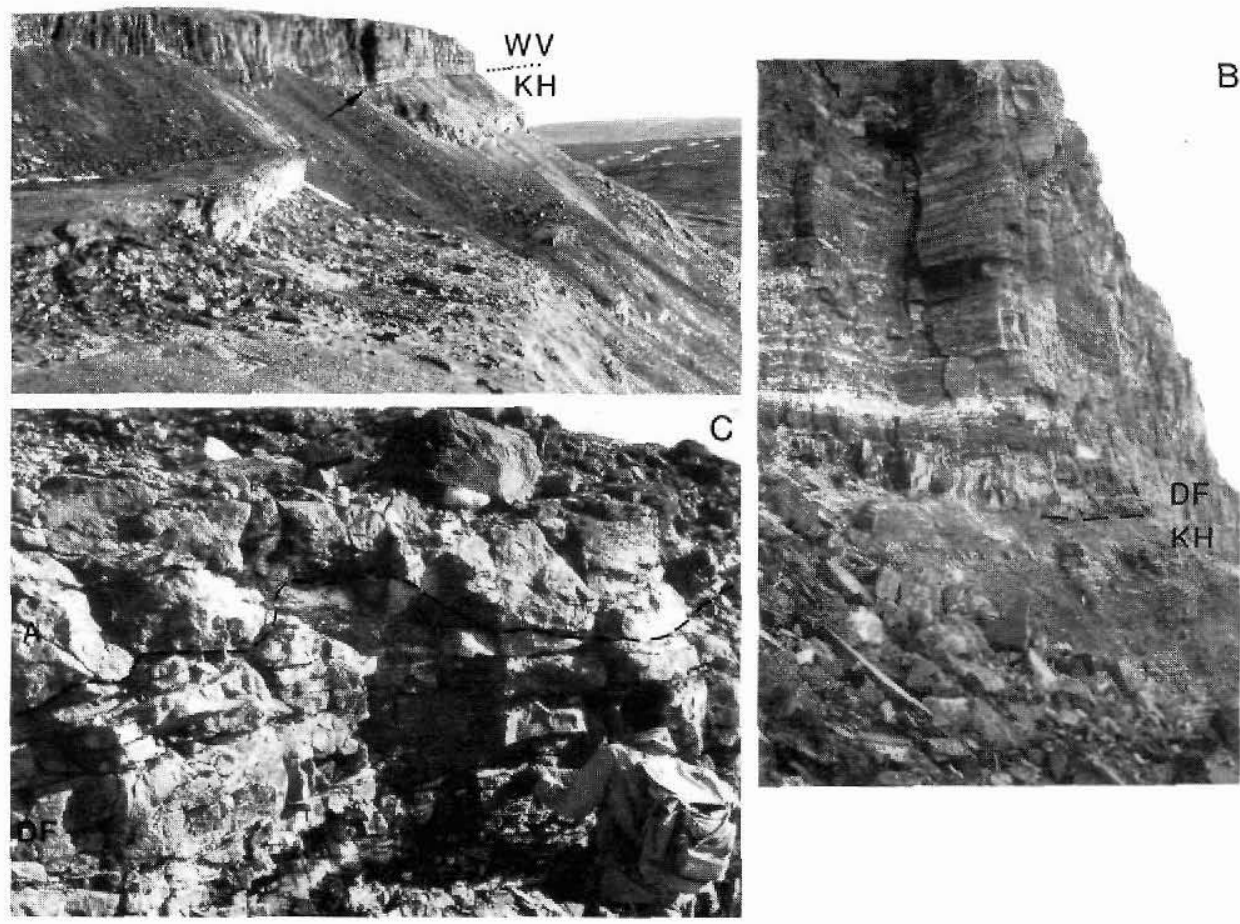

Fig. 11. The Wandel Valley Formation at Kap Holbæk. A, View along western side of the plateau forming Kap Holbæk showing Wandel Valley Formation (WV) overlying siliciclastic sediments of the Kap Holbæk Formation (KH) of late Proterozic age. B, contact between Danmarks Fjord Member (DF) and the underlying Kap Holbæk Formation, arrowed in fig. 11A. C, billowing contact between dark grey weathering limestone of the Amdrup Member (A) and brownish weathering dolomite of the Danmarks Fjord Member (DF). Locality lies just outside the left margin of fig. 11A. These sections form the type locality of the Amdrup Member and the reference locality for the Danmarks Fjord Member of the Wandel Valley Formation.

Land (fig. 6). In Freuchen Land and in westernmost Peary Land overlying sediments of the Morris Bugt Group are referred to the Kap Jackson Formation. In Kronprins Christian Land and Valdemar Glückstadt Land the Wandel Valley Formation is overlain by the Sjælland Fjelde Formation of the Ryder Gletscher Group (Ineson et al., 1986) which is in turn succeeded by the Børglum River Formation.

Distribution. From Kronprins Christian Land to eastern Freuchen Land. Westward across Freuchen Land the formation passes laterally into other formations of the Ryder Gletscher Group. Thus, the Vestervig Elv Member is equivalent to the Cape Webster Formation and the Pyramideplateau Member equates with the Steensby Gletscher Formation (Sønderholm \& Due, 1985; see fig. 5).

The sub-Wandel Valley Formation unconformity is seen to lie within the Warming Land 


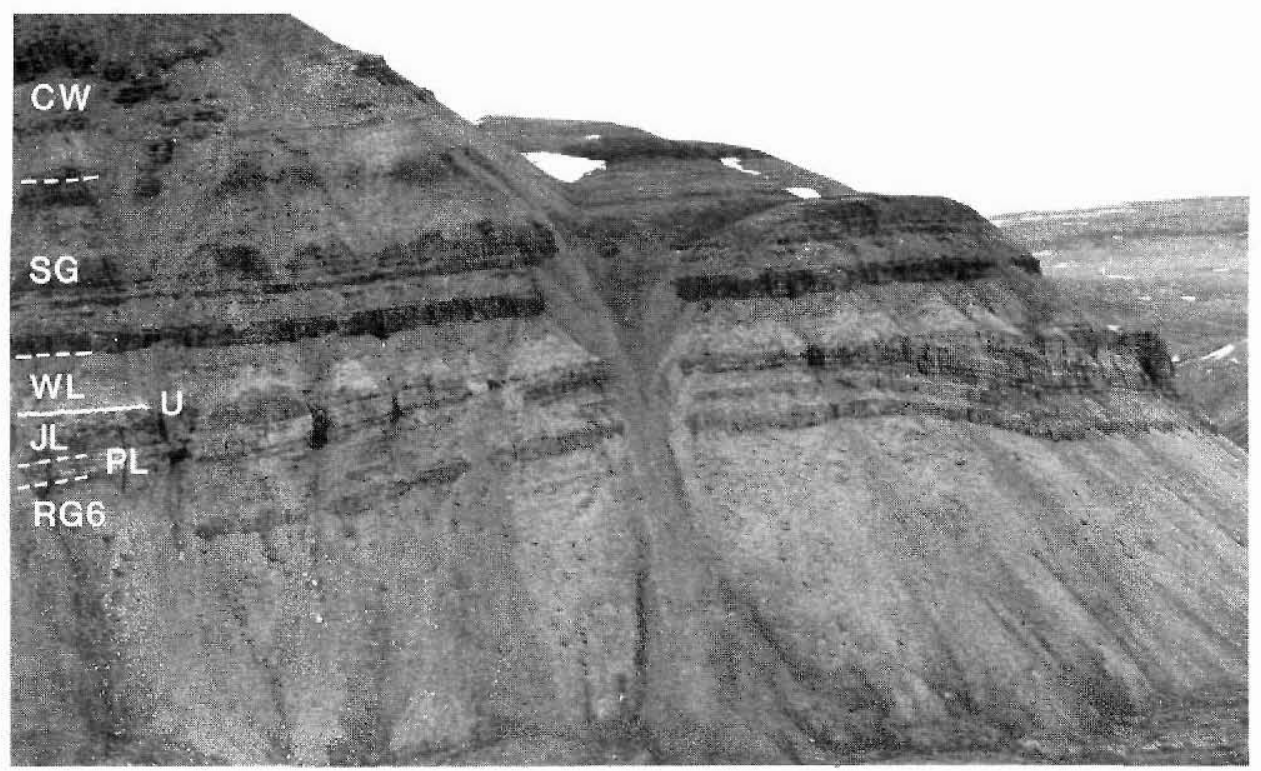

Fig. 12. Shelf sequence equivalent to the Wandel Valley Formation in the land area south of Nares Land, view looking east at locality 1 in fig. 2. The sub-Wandel Valley Formation unconformity (U) is developed within the lowest part of the Warming Land Formation (WL) and truncates older strata across the crest of the small anticline. Height of section about $500 \mathrm{~m}$. CW, Cape Webster Formation; SG, Steensby Gletscher Formation; JL, Johansen Land Formation; PL, Permin Land Formation; RG6, informal formation RG6 of Peel \& Wright (1985). All formations are assigned to the Ryder Gletscher group.

Formation in western areas. Truncation of underlying strata has been discerned as far west as the land area south of Nares Land (figs 2, 12).

Age. Late Canadian (late Early Ordovician) to earliest Late Whiterockian (Middle Ordovician). See discussion of individual members, below.

Sub-division. The Wandel Valley Formation is divided into two members in its type area, namely the Pyramideplateau Member and the overlying Vestervig Elv Member (fig. 5). In Kronprins Christian Land, a tripartite division is recognised, namely the Danmarks Fjord, Amdrup and Alexandrine Bjerg Members (ascending order). In outcrops north of G. B. Schley Fjord in eastern Peary Land (fig. 2) members can not be recognised within the Wandel Valley Formation.

\section{Pyramideplateau Member}

new member

Name. From Pyramideplateau, a plateau area with extensive outcrops of the Wandel Valley Formation on the east side of the lower reaches of Børglum Elv (figs 3, 7B, 9). 

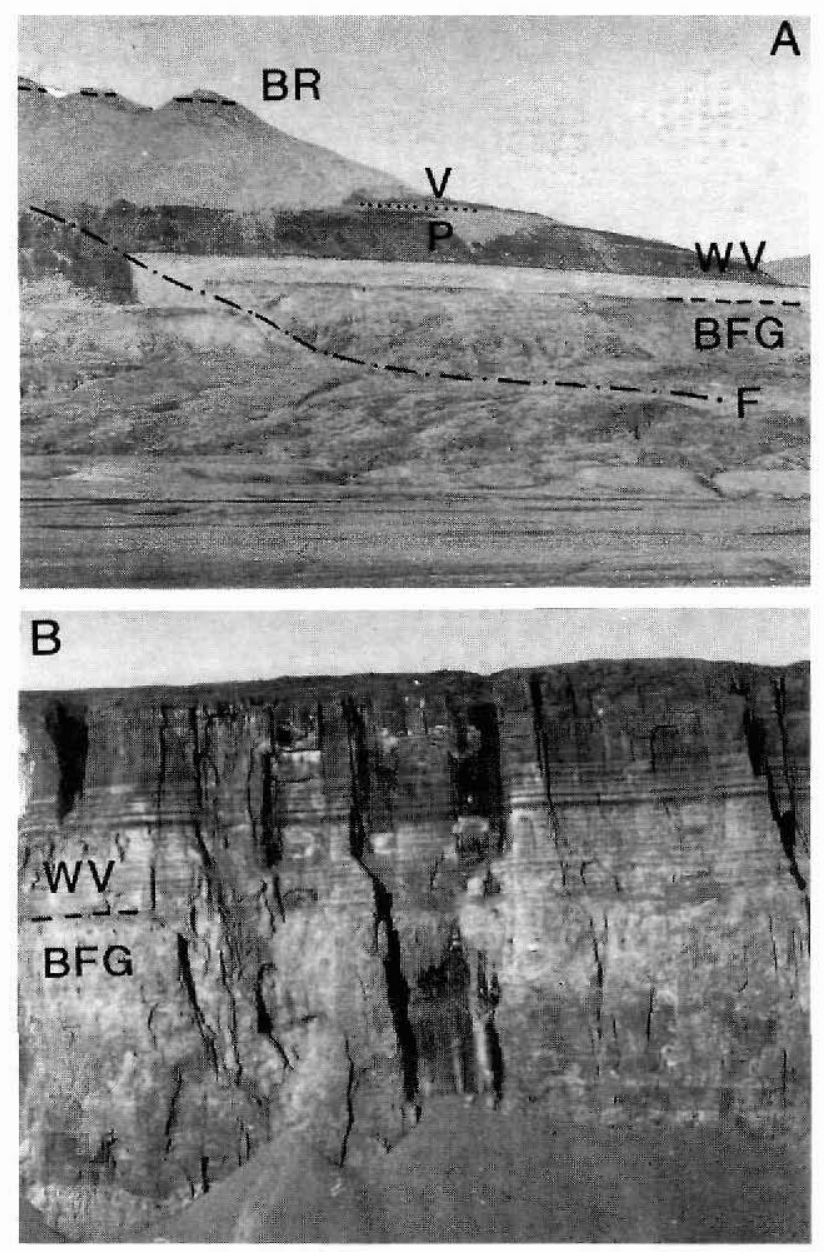

Fig. 13. The Wandel Valley Formation (WV) along Børglum Elv. A, view of locality 3 in fig. 3 showing the typical weathering character of the formation with the pale lower dolomites within the Pyramideplateau Member (P; member thickness $120 \mathrm{~m}$ ) succeeded abruptly by dark burrow-mottled dolomites forming the upper part of the member. Pale weathering dolomites of the overlying Vestervig Elv Member (V) form screes capped by the Børglum River Formation (BR). BFG, Brønlund Fjord Group; F, fault with downthrow to left. B, Wandel Valley Formation (WV; thickness about $120 \mathrm{~m}$ ) overlying the Brønlund Fjord Group (BFG) in cliffs forming the eastern side of Buen, fig. 3, locality 2. The fresh exposure shows the cyclic alternation of pale and dark dolomites not readily discernible on weathered outcrops.

History. Strata assigned to this member in the type locality of the formation were used by Troelsen (1949) as the basis for his description of the formation. The Pyramideplateau Member includes both the lower and middle informal members of Christie \& Peel (1977; see figs 3,8$)$.

Type locality. East side of valley of Børglum Elv downstream of Domkirken; section D of Christie \& Peel (1977; see locality 4 in fig. 3).

Lithology. A description of the type section is given by Christie \& Peel (1977, p. 43, section D, units 2-9). Pale weathering, light grey, thin to medium bedded dolomite with planar to wavy silty laminae, thin beds of intraformational conglomerate and nodules and lenses of chert, dominate the lower part of the member. These alternate with, and subsequently are largely succeeded by, dark grey-brown, burrow-mottled, crystalline dolomite and limey 
dolomite in medium to thick beds. Chert nodules, beds of intraformational conglomerate and small vugs with crystals of quartz and pink carbonate may be locally conspicuous.

The differentiation of the two lithofacies in the Børglum Elv region was deemed sufficiently distinct to promote the recognition of two members by Christie \& Peel (1977); the combination of a pale grey weathering unit and an overlying dark grey weathering forms a most distinctive mapping horizon throughout the area (fig. 13A), although the interbedding of these facies in detail sedimentation is evident in clean exposures (fig. 13B). It is also apparent that varying proportions of dark to pale dolomite are present in different localities, giving only local significance to the recognition of separate members. In northern outcrops, for example at Navarana Fjord and the Perssuaq Gletscher area of J. P. Koch Fjord (figs 2, 14), the Pyramideplateau Member shows no tendency to divide into a lower pale unit and an upper dark unit, although the cyclic alternation of the two facies is evident (figs 10B, 14). South of G. B. Schley Fjord, the two fold division of the Pyramideplateau Member is clear (fig. 15); north of the fjord neither this sub-division nor the division of the formation into two members can be recognised.

Thickness. About $120 \mathrm{~m}$ at the type section. On the east side of Henson Gletscher in extreme western Peary Land, the member attains a thickness of about $140 \mathrm{~m}$ (fig. 10A).

Boundaries. As the basal member of the formation, the Pyramideplateau Member unconformably overlies mainly Cambrian sediments throughout Peary Land (see discussion above). It is conformably overlain by the Vestervig Elv Member, the boundary being drawn where dark grey to black, burrow-mottled dolomites of the Pyramideplateau Member are succeeded by pale to medium grey weathering, silty laminated dolomites of the Vestervig Elv Member.

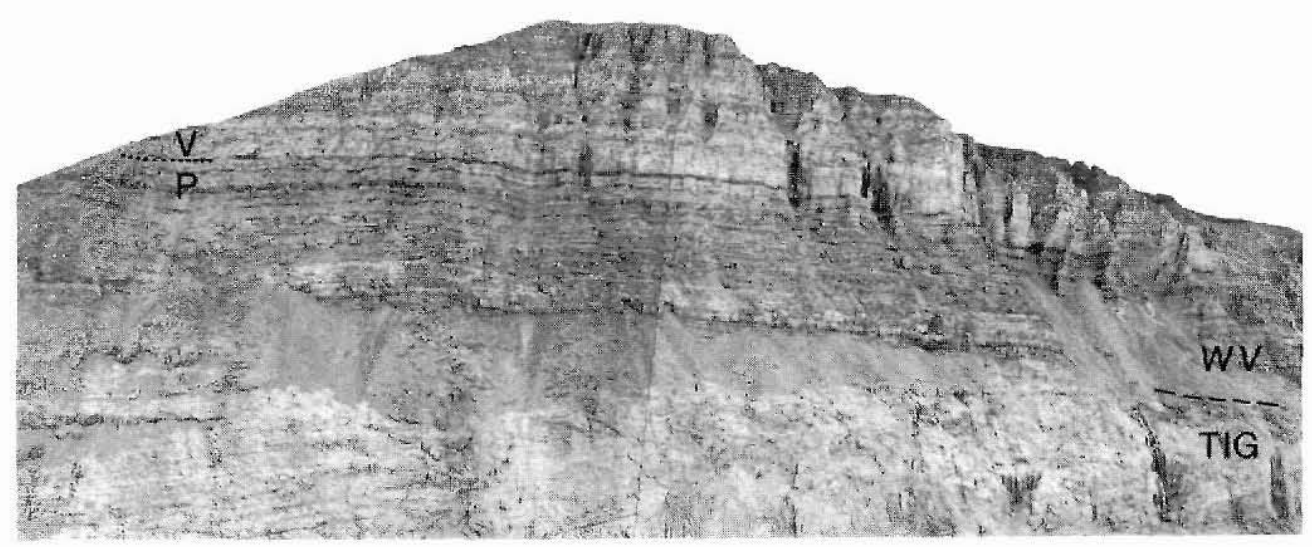

Fig. 14. Wandel Valley Formation (WV; thickness about $300 \mathrm{~m}$ ) overlying the Tavsens Iskappe Group (TIG) in the eastern wall of the glacier at the head of Navarana Fjord in Freuchen Land (fig. 2, locality 4). The sharp distinction between basal pale weathering dolomite and overlying dark weathering dolomite which characterises the Pyramideplateau Member (P) in the type area (fig. 13) is lacking. V, Vestervig Elv Member (photo: F. Surlyk). 


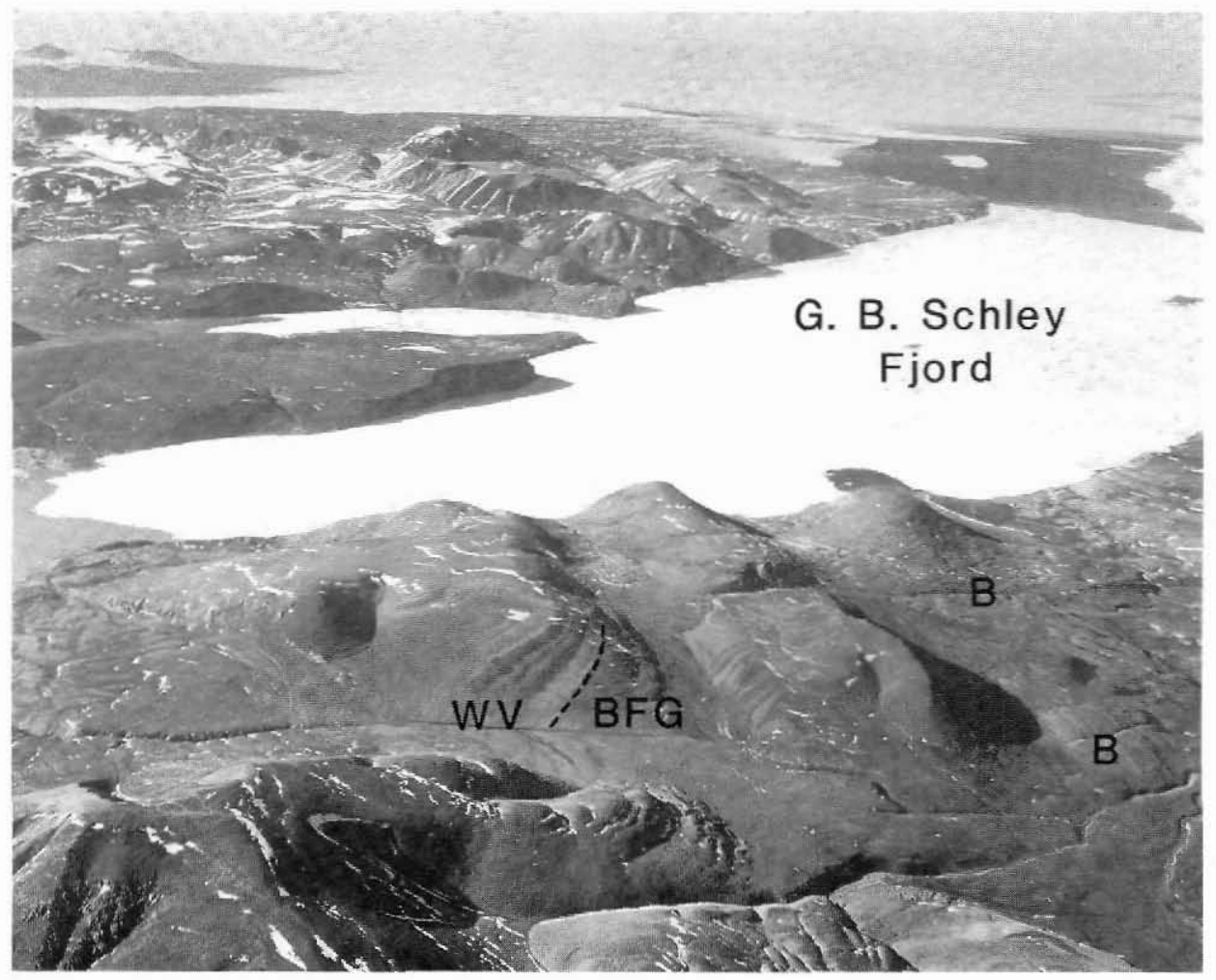

Fig. 15. View north across G. B. Schley Fjord to the mouth of Frederick E. Hyde Fjord (top left) and the Arctic Ocean. The Wandel Valley Formation (WV), with clearly differentiated lower pale weathering and upper dark weathering units comprising the Pyramideplateau Member, unconformably overlies carbonate sediments of the Cambrian Bronlund Fjord Group (BFG). Lower Cambrian fine grained siliciclastic sediments of the Buen Formation (B) form the lower ground to the right. Locality 5 in fig. 2. (Copyright Geodetic Institute, reproduced with permission no. A200/87).

Distribution. Eastern Freuchen Land and Peary Land. The member may be present in undifferentiated outcrops of Wandel Valley Formation in J. C. Christensen Land and in Valdemar Glückstadt Land.

Fauna and age. Macrofossils occur commonly in the dark burrow-mottled dolomites where they are mainly visible as silica-replicas on weathered surfaces. Gastropods dominate, among which the claw-shaped opercula of Ceratopea (fig. 10D) indicate a late Canadian age (Yochelson \& Peel, 1975).

The Pyramideplateau Member contains a moderately diverse conodont assemblage of typical, shallow water biofacies, Midcontinent Realm species of late Canadian age (fig. 16). Unfortunately, this assemblage is a long-ranging, facies-controlled group of limited biostratigraphic utility ranging from low in Fauna D (Ethington \& Clark, 1971) to the top of the O. communis Zone (Ethington \& Repetski, 1984). The characteristic species include Glyp- 
toconus quadraplicatus (Branson \& Mehl), Eucharodus parallelus (Branson \& Mehl), Ulrichodina abnormalis (Branson \& Mehl), Drepanodus concavus (Branson \& Mehl), Tropodus comptus (Branson \& Mehl) and Gen. nov. A, which includes 'Scandodus' sp. 1 of Ethington \& Clark (1982) in its apparatus.

In their study of the Canadian type section at Ibex, Utah, Ethington \& Clark (1982) recognised several potential sub-zonal indicators which they used as the basis for informal biostratigraphic intervals. The Ibex succession is of deeper water origin than the Wandel Valley Formation and none of these index species is present in the Pyramideplateau Member. However, four of the species present have the potential for greater biostratigraphic precision. The first, Cristodus loxoides Repetski, is a characteristic species which, in the El Paso Group, is introduced $45 \mathrm{~m}$ below the base of the $O$. communis Zone (Repetski, 1982). The second species, Gen. nov. B (New Genus 2 of Ethington \& Clark, 1982), was restricted to uppermost Fauna D and the $O$. communis Zone in the Ibex section. The third is Gen. nov. C which was described by Stouge (1982) as Scolopodus? sp. C and was recorded by him only from the $O$. communis Zone in the St George Group of Newfoundland. In Washington Land it is also present in uppermost Fauna D (unpublished GGU data). Lastly, 'Acontiodus' staufferi Furnish is present only in the lower $30 \mathrm{~m}$ of the Pyramideplateau Member and elsewhere in North America is restricted to Fauna $\mathrm{D}$ and the lower half of the $O$. communis Zone. These four species therefore constrain the age of the member to late Fauna D or early $O$. communis Zone. Indirect evidence suggests that the latter is more likely. In Kronprins Christian Land, trilobites from near the base of the formation, in the Amdrup Member, are of Ross-Hintze Zone $\mathrm{H}$ (Fortey, 1986) which correlates with the lower part of the $O$. communis Zone (Ethington \& Clark, 1982). Oepikodus communis itself first occurs $55 \mathrm{~m}$ above the base of the formation in this section, together with Protoprioniodus papiliosus (van Wamel). This first appearance is facies-controlled, in all probability, since at Ibex the latter species is restricted to the upper part of the zone (Ethington \& Clark, 1982). The balance of evidence suggests that the Pyramideplateau Member is of early $O$. communis Zone age.

\section{Vestervig Elv Member}

new member

Name. After Vestervig Elv, a major tributary stream flowing eastward into Børglum Elv (figs 3, 9).

History. This member corresponds to the upper member of the Wandel Valley Formation as described by Christie \& Peel (1977).

Type locality. East side of valley of Børglum Elv, downstream of Domkirken (figs 3, 8, 9). Composite sections $E$ and $F$ of Christie \& Peel (1977, p. 44). It should be noted that unit 1 in the composite section was inadvertently assigned to the upper member of the Wandel Valley Formation. It is evident from comparison with section $D$ that this unit is the upper part of the middle member of Christie \& Peel. Thus, the Vestervig Elv Member corresponds to units 2 to 11 inclusive in composite sections $\mathrm{E}$ and $\mathrm{F}$. 


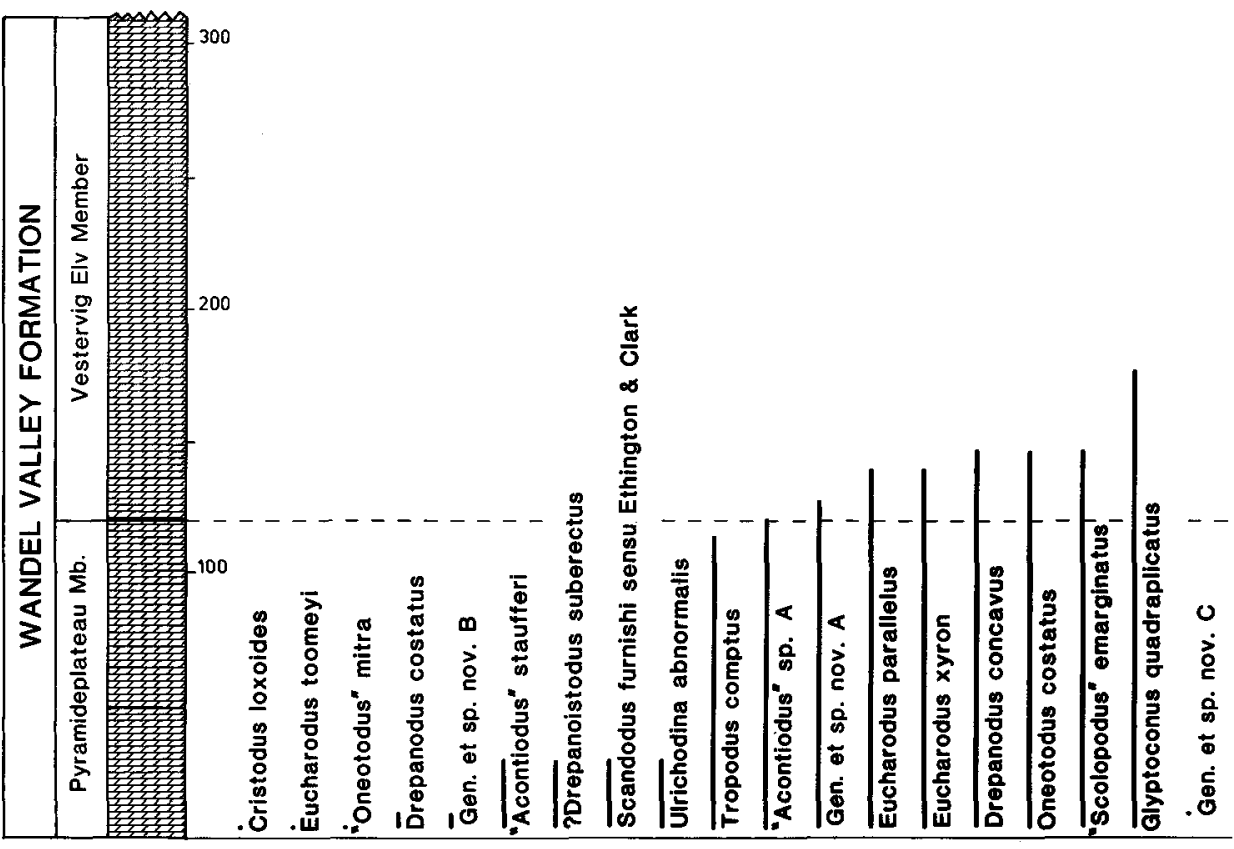

Fig. 16. Range chart of conodont taxa in the Wandel Valley Formation in J. E. Mabillard section JEM 790627-1, central Peary Land. This section corresponds to the type localities of the Pyramideplateau and Vestervig Elv Members (fig. 3, localities 4, 5), but the top of the formation is not present.

Reference sections. Basal beds of the Vestervig Elv Member and the contact with the underlying Pyramideplateau Member are recorded in section D of Christie \& Peel (1977, pp. 42-43; see fig. 3, locality 4; fig. 8), located downstream of the type locality. Upper beds of the Vestervig Elv Member and the transition into the overlying Børglum River Formation are recorded in section G of Christie \& Peel (1977, pp. 45-46) at the mouth of Vestervig Elv (fig. 3, locality 6).

Lithology. Light grey weathering, thin to medium bedded, parallel to wavy laminated dolomites with thin beds of intraformational conglomerate and nodules and lenses of chert.

Thickness. About $200 \mathrm{~m}$ in the type section. This figure, quoted by Christie \& Peel (1977, p. 18 ), is not affected by their manuscript error mentioned above. M. Sønderholm (personal communication, 1988) measured a thickness of $280 \mathrm{~m}$ at the head of Navarana Fjord.

Boundaries. Lower boundary, see description of Pyramideplateau Member. The upper boundary is drawn where grey dolomites of the Vestervig Elv Member are abruptly, but conformably, succeeded by grey limestones of the Børglum River Formation. 


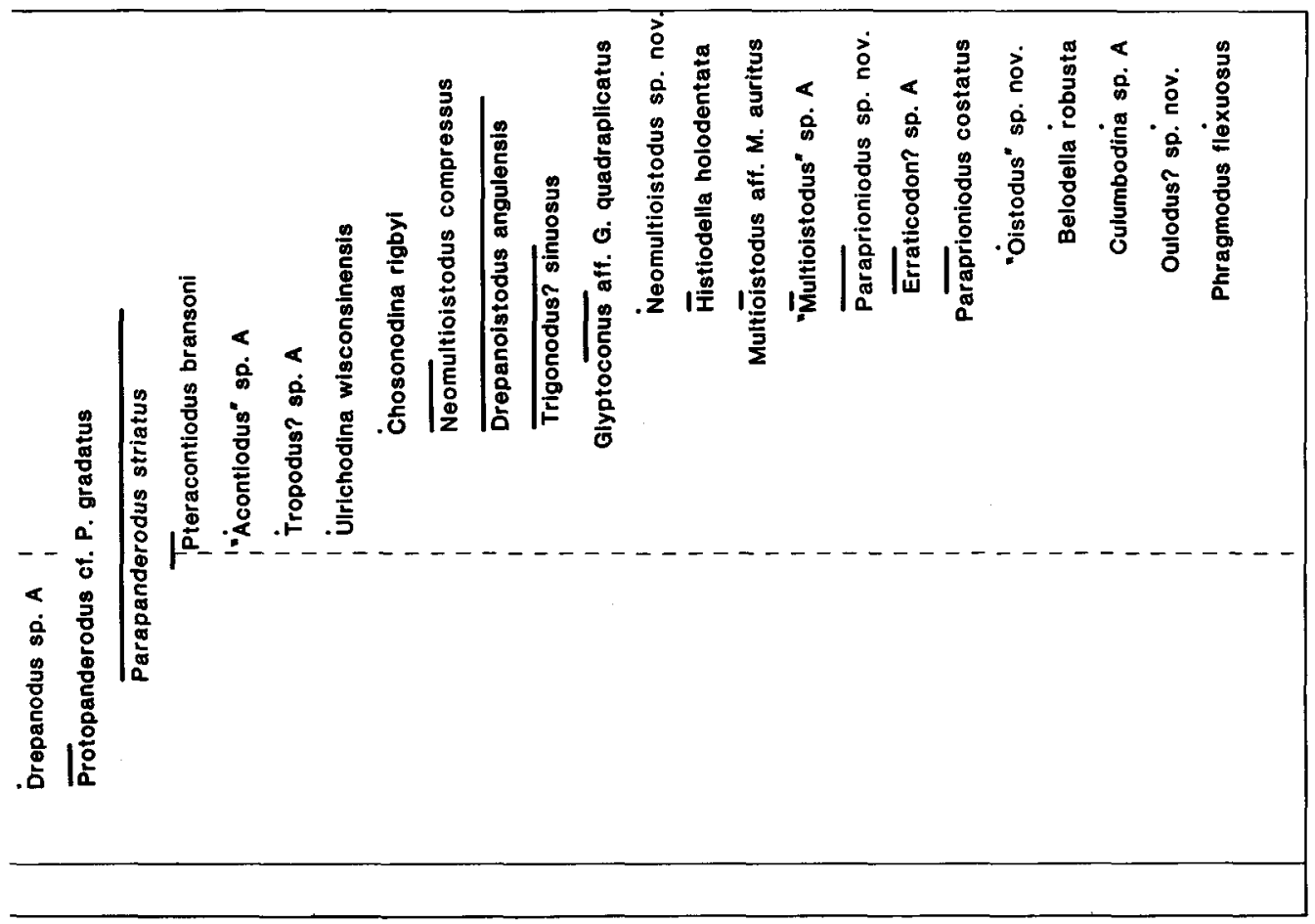

Distribution. Peary Land, westward into Freuchen Land and eastward to Independence Fjord. The member may be present in undifferentiated outcrops of the Wandel Valley Formation in J. C. Christensen Land and Valdemar Glückstadt Land.

Fauna and age. Macrofossils are rare; a few brachiopods and molluscs were seen in outcrops east of Hans Tavsen Iskappe (J. S. P., field observation 1978).

In the Vestervig Elv Member conodont diversity and abundance are far lower than in the underlying member. Few of the species present in the Pyramideplateau Member continue into the overlying member (fig. 16) and of those which do, only G. quadraplicatus and Parapanderodus striatus (Graves \& Ellison) continue for any great distance. The first Whiterockian species are introduced at $48 \mathrm{~m}$ above the base of the member where Chosonodina rigbyi Ethington \& Clark, Neomultioistodus compressus Harris \& Harris, Drepanoistodus angulensis Ethington \& Clark and Trigonodus? sinuosus (Mound) have their lowest occurrences, indicating a position within the $H$. altifrons Zone of Sweet (1984). The Canadian-Whiterockian boundary occurs at or just above the Pyramideplateau Member Vestervig Elv Member boundary. Few species have their first appearance in the overlying $H$. sinuosa Zone (Ethington \& Clark, 1982; A. G. Harris \& J. E. Repetski, personal communication) and this interval is not recognised in the Vestervig Elv Member. The next youngest 
zone, the $\boldsymbol{H}$. holodentata Zone, is represented by the eponymous species together with Paraprioniodus costatus (Mound), T? sinuosus, D. angulensis and Gen. nov. D, a new multioistodontid genus (New Genus 4 of Ethington \& Clark, 1982) (figs 16, 17). The zone extends to within $81 \mathrm{~m}$ of the top of the formation where species associated with the $P$. flexuosus Zone are introduced and include $P$. flexuosus (with coniform M element), Belodella robusta Ethington \& Clark, Erraticodon balticus Dzik and Erismodus asymmetricus (Branson \& Mehl) (fig. 17). At $22 \mathrm{~m}$ below the top Appalachignathus delicatulus Bergström et al. is introduced and $5 \mathrm{~m}$ higher Phragmodus sp. nov. (with dolabrate M element) appears. The range base of the latter is coincident with the base of the Cahabagnathus friendsvillensis Zone (Sweet, 1984) and is indicative of an earliest Late Whiterockian age for the Wandel Valley Formation (Vestervig Elv Member) - Børglum River Formation boundary.

\section{Danmarks Fjord Member}

Fränkl, 1955

Name. After Danmark Fjord, eastern North Greenland (figs 4, 18).

History. The former Danmarks Fjord Dolomite of Fränkl (1955), see discussion in Peel (1980a), Peel et al. (1981) and Smith \& Peel (1986), and below.

Type locality. Peel et al. (1981) designated Kap Holbæk, the peninsula in southern MyliusErichsen Land on the western side of Danmark Fjord (figs 4, 18B), as type locality on account of the name of the unit and the tendency for previous authors to use the description by Adams \& Cowie (1953) from this locality in characterising this unit (see also Smith \& Peel (1986). Unfortunately, they overlooked the fact that Troelsen (1956, p. 27) had earlier designated the type locality of the Danmarks Fjord Dolomite along Sæfaxi Elv in the area east of Centrum Sø (fig. 4). This latter locality was described by Fränkl (1955) but he also 


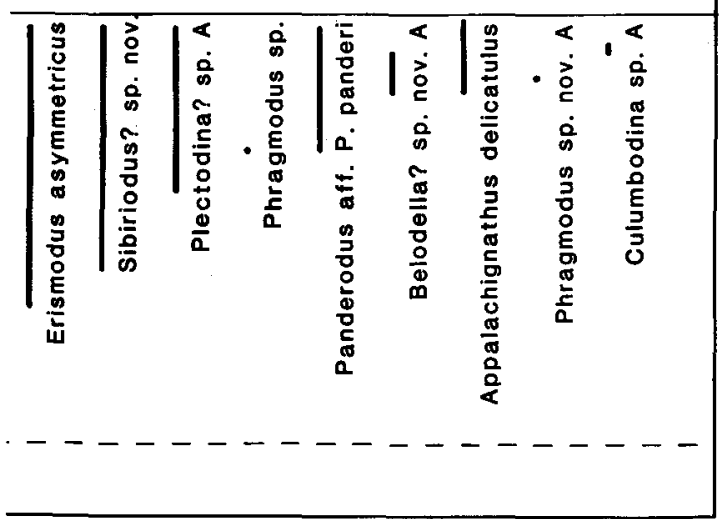

Fig. 17. Composite range chart of conodont taxa in the upper part of the Vestervig Elv Member of the Wandel Valley Formation in J. E. Mabillard sections JEM 790627-2 and JEM 790701-1. The latter section corresponds to the reference section of the Vestervig Elv Member (locality 6 in fig. 3); the former is located across the boundary with the Børglum River Formation in the cliffs above locality 4 in fig. 3 .

indicated the presence of the unit at Kap Holbæk on Danmark Fjord. Following Troelsen's action, the status of the locality at Sæfaxi Elv as the type locality of the member is self-evident. However, its reinstatement introduces uncertainty into arguments presented by Peel et al. (1981) and Smith \& Peel (1986) for considering the Danmarks Fjord Dolomite to be the basal member of the Wandel Valley Formation in Kronprins Christian Land since the type locality at Sæaxi Elv has not been examined in the course of the present study. The arguments of Peel $e t$ al. and Smith \& Peel concerning lithology and stratigraphic position, and the samples processed for conodonts, were all derived from localities at Kap Holbæk and the eastern shore of Danmarks Fjord (Smith \& Peel, 1986; see figs 4, 18B). Acceptance of the Danmarks Fjord Dolomite as the basal member of the Wandel Valley Formation thus assumes that the localities of Fränkl (1955, Sæaxi Elv) and Adams \& Cowie (1953, Kap Holbæk) lie within the same unit. It may be added that this correlation has been accepted by earlier authors (including Fränkl) without adverse comment although it does not appear that anyone has examined both localities.

Hurst (1984, p. 61) could not assign carbonates overlying the Danmarks Fjord Dolomite at Sæfaxi Elv to any of the formations known elsewhere in Kronprins Christian Land and proposed a new formation for these (Harefjeld Formation). His statement that he found no evidence to suggest that any part of the poorly exposed and poorly fossiliferous Harefjeld Formation was as old as the Børglum River Formation (which is itself younger than the Wandel Valley Formation, see fig. 6) inevitably casts some doubt upon the age of the underlying Danmarks Fjord Dolomite at this locality.

Until future field work resolves the relationship between the localities at Sæfaxi Elv and Kap Holbak there remains little choice but to tentatively accept the correlation originally proposed by Fränkl (1955) himself but with the recognition that opinions expressed by Smith $\&$ Peel (1986) and herein concerning the nature and status of the Danmarks Fjord Dolomite are based on localities at or near Kap Holbæk.

Reference locality. West side of the peninsula forming Kap Holbæk (Smith \& Peel, 1986, fig. 2 ; see figs $11,18 \mathrm{~B})$. 

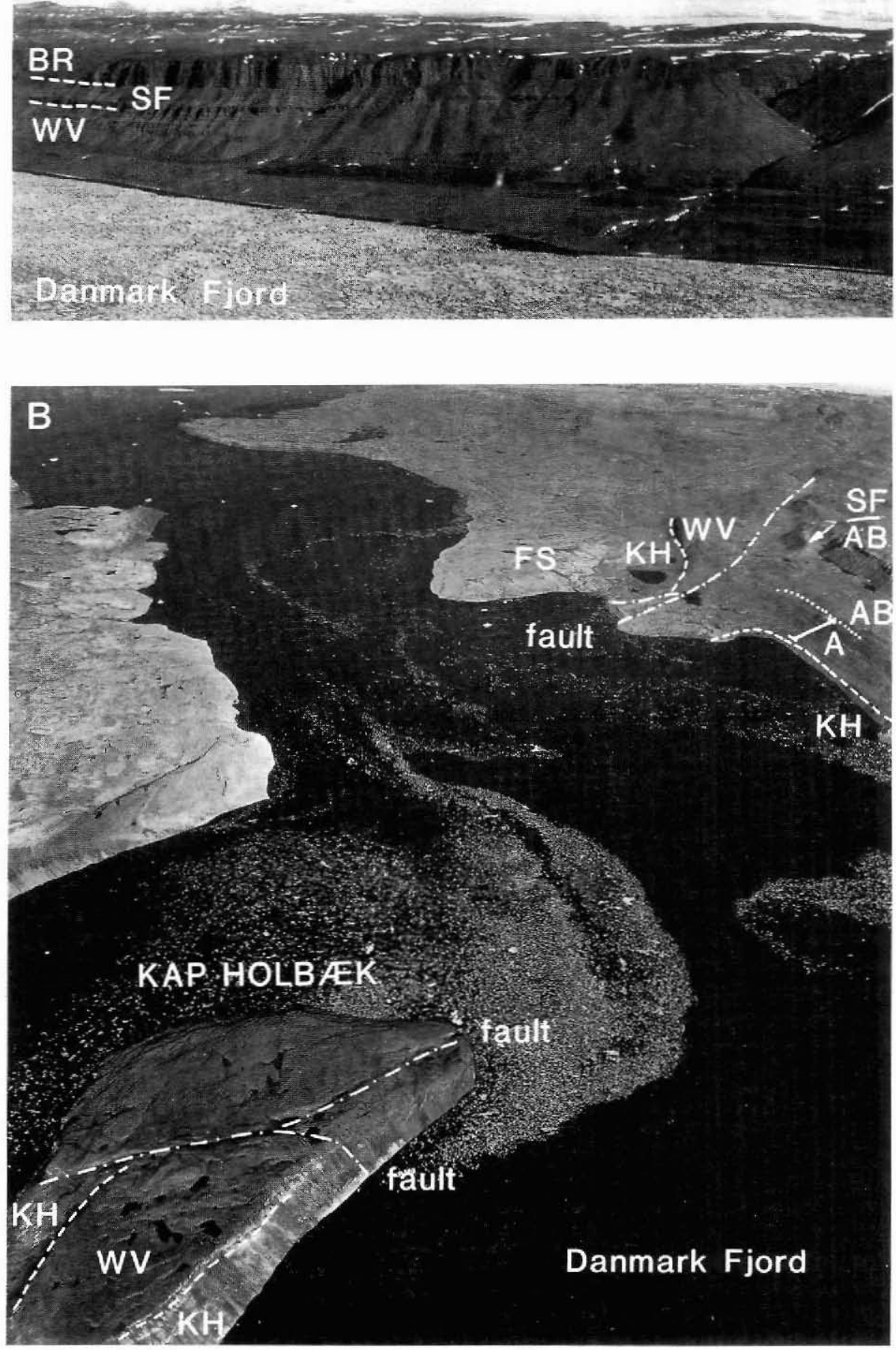
Lithology. At the reference locality the member is brown weathering, grey to dark grey dolomite with undulating laminar or lenticular bedding. The laminated horizons often show small domed stromatolites. Black cherts are common and thin beds of intraformational conglomerate and oolite occur throughout. Fränkl (1955) described the unit as being composed of light coloured dolomite with chert, with some dark coloured limy bands and a bed of quartzite; the light colour is also seen in outcrops of the member along the western shore of Kronprins Christian Land.

Thickness. 10-12 m, although Fränkl (1955) reported 10-30 m at Sæfaxi Elv.

Boundaries. At Kap Holbæk the member overlies the Kap Holbæk Formation (late Proterozoic) without apparent angular discordance (fig. 11A, B) although small faults penetrating the latter do not appear to displace the Danmarks Fjord Member. Fränkl (1955) described an irregular unconformable relationship with siliciclastic sediments which he referred to the Kap Holbæk Formation at Sæfaxi Elv. At Kap Holbæk the irregular upper surface of the Danmarks Fjord Member is abruptly overlain by dark grey limestone of the Amdrup Member (fig. 11C), but the boundary is gradational in westernmost Kronprins Christian Land. Fränkl implied a conformable relationship with overlying carbonates at Sæfaxi Elv.

Distribution. Kronprins Christian Land and adjacent Mylius-Erichsen Land. The presence of the member in poorly exposed and undifferentiated outcrops of the Wandel Valley Formation in Valdemar Glückstadt Land and J. C. Christensen Land is uncertain, although Smith \& Peel (1986, p. 10) tentatively assigned the basal few metres of the formation in Valdemar Glückstadt Land to this member.

Fauna and age. No macrofossils are known from the member. The member contains the same long-ranging assemblage of conodonts present in the Pyramideplateau Member in Peary Land (fig. 19) and the fauna has been documented by Smith \& Peel (1986). As discussed under the Pyramideplateau Member, a lower $O$. communis Zone age is most likely.

Fig. 18. The Wandel Valley Formation around Danmark Fjord. A, cliffs on the eastern side of Danmark Fjord showing the Wandel Valley Formation (WV) overlain by the Sjælland Fjelde (SF; thickness about $120 \mathrm{~m}$ ) and Børglum River (BR) Formations. Locality 3 in fig. 4. B, view across Kap Holbæk and Danmark Fjord toward western Kronprins Christian Land. Localities at Kap Holbæk illustrated in fig. 11 lie on the extreme left (north-west) side of the promontory, south of the fault. A, reference section of the Amdrup Member; AB, Alexandrine Bjerge Member, the type section which includes the boundary with the overlying Sjælland Fjelde Formation (SF) is arrowed. FS, Fyns Sø Formation (Proterozoic); KH, Kap Holbæk Formation (Proterozoic); WV, undifferentiated Wandel Valley Formation. (Copyright Geodetic Institute, reproduced with permission no. A200/87). 


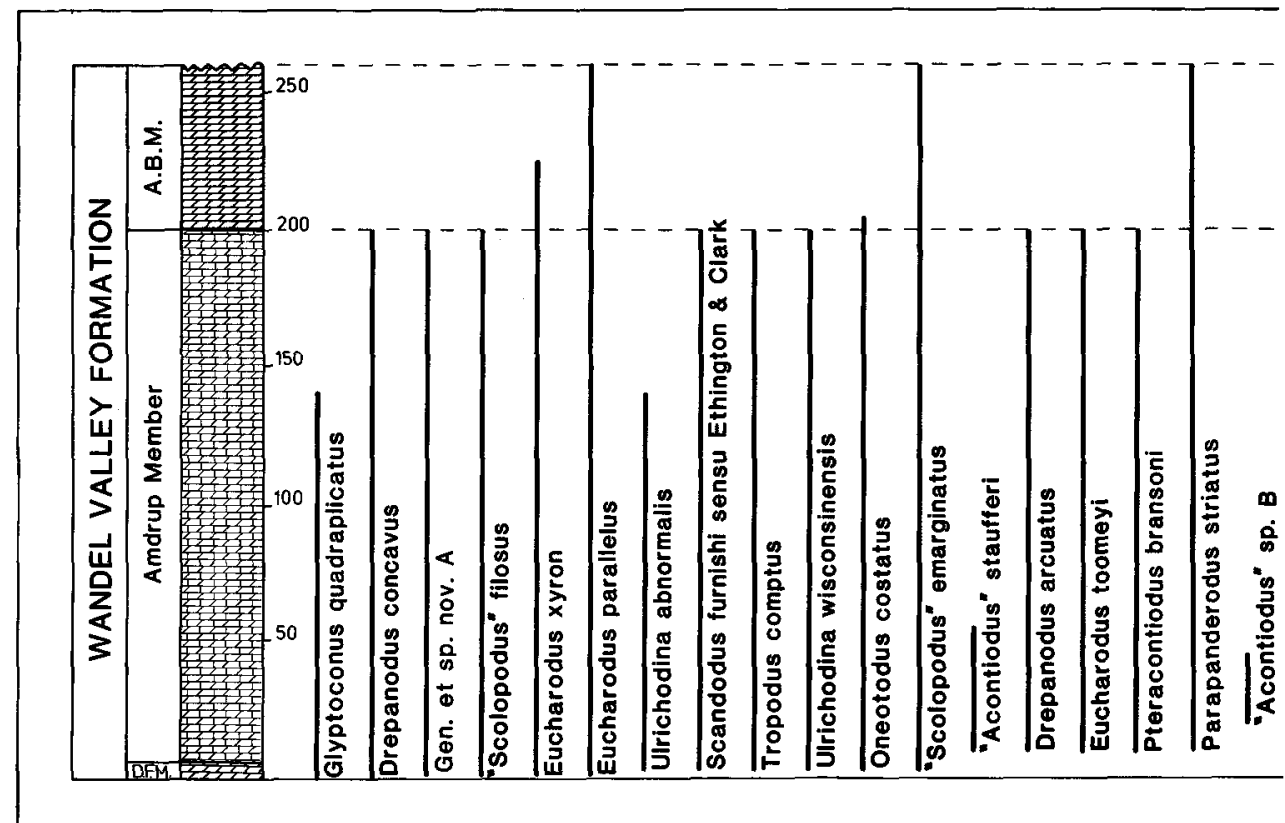

Fig. 19. Range chart of conodont taxa in the Wandel Valley Formation in western Kronprins Christian Land at J. S. Peel locality JSP 800702-1. This is the reference locality of the Amdrup Member illustrated in fig. 18B and as locality 2 in fig. 4. DFM, Danmarks Fjord Member; ABM, Alexandrine Bjerge Member.

\section{Amdrup Member}

Cowie, 1971

Name. Presumably after Amdrup Land (fig. 1), at the eastern extremity of Kronprins Christian Land, although the Wandel Valley Formation has no known outcrop in this area.

History. The Amdrup Formation of Cowie (1971, pp. 366-368), subsequently modified by Scrutton (1975); part of the original Centrum Limestone of Adams \& Cowie (1953). The formation was reduced in status to a member of the Wandel Valley Formation by Peel et al. (1981).

Cowie (1971) assigned $240 \mathrm{~m}$ of fossiliferous limestone and dolomitic limestone to the Amdrup Formation but Scrutton (1975) separated the upper $50 \mathrm{~m}$ as a new formation which he informally termed the 'Opikina Limestone'. The latter may in part be equivalent to the Alexandrine Bjerg Member (= upper member) of the Wandel Valley Formation or to the Sjalland Fjelde Formation of Ineson et al. (1986).

Type locality. Strata originally described by Adams \& Cowie (1953) and subsequently assigned to the Amdrup Formation as restricted by Scrutton (1975) occur at two localities 


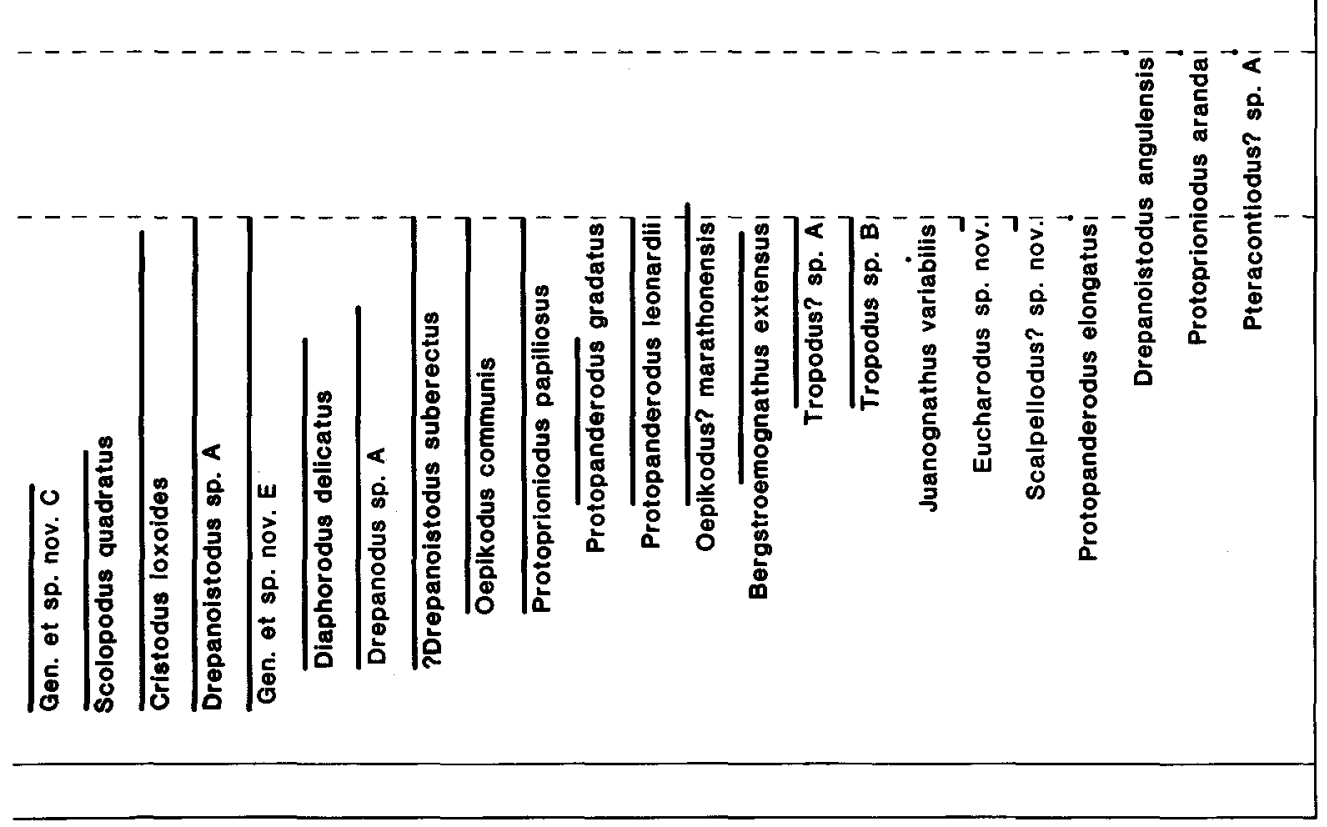

around the head of Danmark Fjord (fig. 4). The lower beds were examined at Kap Holbæk (locality 1 of Adams \& Cowie, 1953; see figs 4, 18B) while most of the unit was examined at a second locality about $10 \mathrm{~km}$ east of Fyn Sø (fig. 4, locality 1). Kap Holbæk is here designated as type locality.

Reference localities. Locality 2 of Adams \& Cowie (1953) which was not visited in the course of the present study but which lies $25-30 \mathrm{~km}$ south and along strike from a second reference section designated on the western shore of Kronprins Christian Land (fig. 4, localities 1, 2; fig. 18B).

Lithology. Dark weathering, dark grey, medium to thick bedded, bioturbated limestones and dolomitic limestones. Thin lenticular, scoured beds of skeletal grainstone are common as are intraformational flat-pebble conglomerates and nodules of black chert.

Thickness. Only a few tens of metres remain at the type locality due to present day erosion levels but the thickness is about $200 \mathrm{~m}$ in the second reference section.

Boundaries. See discussion of Danmarks Fjord Member, above. The Amdrup Member is succeeded with apparent conformity by the Alexandrine Bjerge Member (fig. 18B) but the boundary has not been examined in detail. 
Distribution. The member occurs throughout western Kronprins Christian Land and may be present in undifferentiated outcrops of Wandel Valley Formation in Valdemar Glückstadt Land and J. C. Christensen Land.

Fauna and age. Fortey \& Peel (1983) have described the trilobite Ceratopeltis latilimbata Poulsen from the lowest beds of the member at Kap Holbæk. Adams \& Cowie (1953) record several species of trilobites from the same locality, but this material has not been described. Fortey (1986) described trilobites from the lower part of the member in its second reference section which he considered indicative of the Ross-Hintze Zone $\mathbf{H}$. Opercula of the gastropod Ceratopea billingsi are known from several localities (Peel, 1980b); the species is also known from the Durness Limestone of Scotland, the Narwhale Sound Formation of East Greenland and the Cape Norman area of Newfoundland.

The Amdrup Member contains the most diverse conodont assemblage of the Early Ordovician members of the Wandel Valley Formation (fig. 19). In addition to the shallowwater biofacies species present in Peary Land the member also contains deeper water species found in the Cape Weber Formation of East Greenland. These include O. communis, Protopanderodus gradatus Serpagli, Protopanderodus leonardii Serpagli, Oepikodus? marathonensis (Bradshaw) and Bergstroemognathus extensus (Graves \& Ellison). Unfortunately the environment was still too restricted to include the potential sub-zonal indices utilised by Ethington \& Clark (1982) and a finer division of the member is not possible.

\section{Alexandrine Bjerge Member}

new member

Name. After Alexandrine Bjerge, a chain of hills in western Kronprins Christian Land, parallel to the coast of Danmark Fjord (fig. 4).

History. Although part of the embracive and now abandoned Centrum Limestone of Adams \& Cowie (1953), this member was first recognised as a separate (but un-named) unit of the Wandel Valley Formation by Peel et al. (1981, see also Peel, 1982, 1986, Ineson et al., 1986).

Type locality. An isolated hill on the western side of Sjælland Fjelde, about $4 \mathrm{~km}$ east of Danmark Fjord (fig. 4, locality 2; fig. 18B). This is also the type locality of the Sjælland Fjelde Formation (see Ineson et al., 1986, figs 1,2) which conformably overlies the Wandel Valley Formation (and hence the Alexandrine Bjerge Member) in Kronprins Christian Land. Only the uppermost beds of the member are exposed in this short section but the member is also exposed in cliffs immediately south-east of the type locality.

Reference localities. The member is well exposed in coastal cliffs along Danmark Fjord (figs 4, 18A).

Lithology. The Alexandrine Bjerge Member is lithologically similar to the Vestervig Elv Member of Peary Land. It is dominated by pale weathering, light to medium grey, thin to 
medium bedded, laminated dolomite which commonly weathers into plates. Intraformational conglomerates and shaly partings are common, while desiccation cracks and stromatolites occur locally.

Thickness. About $200 \mathrm{~m}$, but complete sections have not been measured in the structurally complicated terrain in western Kronprins Christian Land.

Boundaries. The Alexandrine Bjerge Member conformably overlies the dark weathering, cliff-forming limestones and limey dolomites of the Amdrup Member throughout Kronprins Christian Land. It is itself conformably overlain by the Sjalland Fjelde Formation (figs 18A, $B)$, the basal beds of which in the type section are argillaceous bioturbated lime mudstones with intraformational conglomerate lenses (Ineson et al., 1986, p. 29).

Distribution. Kronprins Christian Land. Ineson et al. (1986) speculated that the overlying Sjælland Fjelde Formation may also occur in Valdemar Glückstadt Land, in which case the Alexandrine Bjerge Member would be present in that area in the currently undifferentiated Wandel Valley Formation.

Fauna and age. Macrofossils have not been reported or seen in the field. As in the case of the Pyramideplateau Member - Vestervig Elv Member boundary, very few species of conodonts continue across the Amdrup Member - Alexandrine Bjerge Member boundary (fig. 19). Those which do include E. parallelus, 'Scolopodus' emarginatus Barnes \& Tuke and $P$. striatus. At $60 \mathrm{~m}$ above the base of the member, $D$. angulensis is introduced and Protoprioniodus aranda Cooper is present in the same sample. The two species do not have overlapping ranges at Ibex; the former appears in the lowermost Whiterockian and the latter is restricted to the Canadian (Ethington \& Clark, 1982). The presence of both in the same sample probably indicates a position close to the boundary. Sample coverage through the member is very poor and the next productive sample is $30 \mathrm{~m}$ below the top. It contains the long-ranging $T$.? sinuosus and the new multioistodontid species present in the Vestervig Elv Member. A sample $8 \mathrm{~m}$ above the base of the overlying Sjælland Fjelde Formation is more diagnostic since it contains $P$. flexuosus (with coniform M element). The top of the Alexandrine Bjerge Member is therefore within, or at the base of, the $P$. flexuosus Zone corresponding to a late Middle Whiterockian age. This is older than the top of the upper member of the Wandel Valley Formation in Peary Land and is a consequence of the recognition of the Sjælland Fjelde Formation of Ineson et al. (1986; see figs 5, 6). The Vestervig Elv Member of Peary Land is the lateral equivalent of both the Alexandrine Bjerge Member and the Sjalland Fjelde Formation of Kronprins Christian Land.

\section{Correlation with other parts of Greenland and the Canadian Arctic Islands}

To the west of Peary Land, from western Freuchen Land to Warming Land (figs 1,2), the lower part of the Wandel Valley Formation has been correlated lithostratigraphically with the Steensby Gletscher Formation (Sønderholm \& Due, 1985). The presence of Ceratopea in the latter confirms an equivalence to the Pyramideplateau Member (fig. 5). Further west, in Washington Land, the base of the $O$. communis Zone is well-constrained and is almost coincident with the base of the Nunatami Formation which consequently is also a lateral 
equivalent of the Pyramideplateau Member. The Cape Webster Formation of the Washington Land - western Freuchen Land area is lithologically very similar to the Vestervig Elv Member (Peel, 1982) and conodont studies confirm this stratigraphic relationship (unpublished GGU data).

The Nunatami and Cape Webster Formations have in turn been correlated with the Eleanor River and Bay Fiord Formations respectively of the Canadian Arctic Islands (Peel \& Christie, 1982; Peel, 1982). Conodonts of the Eleanor River Formation are principally of the long-ranging, shallow water biofacies group present in the Pyramideplateau Member. $O$. communis is present only in the upper quarter of the formation but is associated with $P$. aranda, and Oistodus multicorrugatus Harris (Nowlan, 1976) both of which are introduced only in the uppermost $O$. communis Zone (Ethington \& Clark, 1982; Ethington \& Repetski, 1984).

The Lower - lower Middle Ordovician succession in East Greenland is substantially thicker and more typically subtidal in character than that in North Greenland. The base of the $O$. communis Zone occurs $650 \mathrm{~m}$ below the top of the $1165 \mathrm{~m}$ thick sequence of subtidal lime mudstones of the Cape Weber Formation on Ella $\varnothing$ (Smith, 1985; see fig. 1) and the upper part of that formation is thus equivalent to the Danmarks Fjord and Amdrup Members of Kronprins Christian Land (fig. 5). The regression event at the CanadianWhiterockian boundary recorded by the Vestervig Elv and Alexandrine Bjerge Members is marked in East Greenland by the Narwhale Sound Formation which ranges through to the $H$. holodentata Zone (Smith, 1985). It is overlain by the Heimbjerge Formation which marks a return to subtidal conditions and which extends into the Cahabagnathus sweeti Zone (Smith, 1982, 1985). The Vestervig Elv Member, the Alexandrine Bjerge Member and the Sjælland Fjelde Formation are equivalent to the Narwhale Sound Formation and the bulk of the Heimbjerge Formation.

\section{Correlation with Svalbard}

The Ordovician of Svalbard (figs 1,5) is rather poorly known in comparison to that of Greenland and Canada, but strata coeval with the Wandel Valley Formation are present in Ny Friesland, the Hornsund area and on Bjørnøya (Birkenmajer, 1981). The Ny Friesland sequence is the most researched; the Kirtonryggen Formation of Early Ordovician age is divided into three members, the Spora, Basisletta and Nordporten Members (Fortey \& Bruton, 1973). The boundary between the last-named two members is marked by a transition from an at least in part intertidal sequence of alternating dolomites and limestones with intraformational conglomerates to pale, massive limestones. The upper $145 \mathrm{~m}$ of the $220 \mathrm{~m}$ thick Nordporten Member comprise grey or brown limestones with buff dolomitic burrowmottling (Fortey \& Bruton, 1973), a lithology common in the Amdrup Member of the Wandel Valley Formation. Trilobites from the Nordporten Member are of Ross-Hintze Zone $\mathrm{H}$ and enhance the similarity with the Amdrup Member (fig. 19). The lower part of the Nordporten Member contains the typical shallow water conodont assemblage whilst the change to burrow-mottled limestones is reflected by the incoming of more offshore genera such as Bergstroemognathus and Oepikodus (Fortey \& Barnes, 1977) which are also present in the Amdrup Member and the Cape Weber Formation.

Deposition of the Nordporten Member was terminated by platform foundering which gave rise to the deeper water limestones and shales of the Valhallfonna Formation (Fortey, 
1979). The dramatic change in lithology is matched by that in the trilobite and conodont faunas, with the latter switching from Midcontinent to North Atlantic affinity (Fortey \& Barnes, 1977). Although the late Canadian - Early Whiterockian age of the Valhallfonna Formation is comparable to that of the upper Amdrup Member - lower Alexandrine Bjerge Member, the similarity breaks down due to the strong tectonic influence on sedimentation in the Ny Friesland unit.

There has been no detailed palaeontological study and relatively little sedimentological work on the succession in the Hornsund area of southern Spitsbergen (Laptas, 1986). The Ordovician sequence was divided into five formations by Birkenmajer (1978) of which only the upper two, the Nigerbreen Formation (80-120 m) and the overlying Hornsundtind Formation ( $500 \mathrm{~m}$; see fig. 5), have yielded a fauna to date. Both of these units contain Ceratopea and Major \& Winsnes (1955) also recorded a more diverse late Canadian macrofauna from the younger formation. The presence of Ceratopea demonstrates that the two Hornsund units are of the same age as the Danmarks Fjord - Amdrup Members and the Pyramideplateau Member. Lithologically, the Nigerbreen Formation comprises black limestones with buff, dolomitic burrow-mottling comparable to the Nordporten Member and the Amdrup Member. The Hornsundtind Formation is a monotonous sequence of grey subtidal lime mudstones similar in lithology to the Cape Weber Formation. It is overlain by a rather enigmatic and probably heterogeneous group of sediments, the Arkfjellet 'Series', recognised to the south of Hornsund by Major \& Winsnes (1955). Some of the sediments which they included in the group are probably of Precambrian age but at the type locality the conformable relationship with the underlying Hornsundtind Formation ascribed to them by Birkenmajer (1978) seems to be valid.

The least studied Ordovician in Svalbard is that on Bjørnøya (figs 1, 5). Traditionally, two units have been recognised, the Younger Dolomite and the Tetradium Limestone (Holtedahl, 1920a; Horn \& Orvin, 1927) although Krasil'shchikov \& Livshits (1974) combined them as members of the Ymerdalen Formation. The Younger Dolomite is composed of recessive, cryptalgally laminated dolomites with cross-bedded quartzites and quartzitic dolomites at the base. The unit contains a Canadian macrofauna (Holtedahl, 1920a) but a more detailed estimate of age is not possible since the fauna is sparse and in need of revision. The overlying Tetradium Limestone consists of dark, cliff-forming micrites containing a moderately abundant macrofauna which includes Tetradium, Rafinesquina, Gonioceras and Actinoceras (Holtedahl, 1920b). All of these genera are present at the base of the Morris Bugt Group in North Greenland. The Younger Dolomite - Tetradium Limestone boundary may thus be correlated with the Wandel Valley Formation - Børglum River Formation boundary and the Younger Dolomite is, at least in part, equivalent in age to the Wandel Valley Formation. At present it cannot be said whether the bases of the Younger Dolomite and the Wandel Valley Formation are also of similar age but conodont studies currently underway should clarify this matter.

Acknowledgements. The assistance and companionship of fellow participants in GGU field programmes in North Greenland (1974-85) is gratefully acknowledged. Participation in the 1986 Cambridge Arctic Shelf Programme expedition permitted examination by M. P. S. of the Ordovician sequences on Bjørnøya and in the Hornsund area. J. R. Ineson and M. Sønderholm provided unpublished information and reviewed the manuscript. Bente Thomas and Jacob Lautrup are thanked for technical assistance with illustrations. Cambridge Earth Sciences Publication 1097. 


\section{References}

Adams, P. J. \& Cowie, J. W. 1953: A geological reconnaissance of the region round the inner part of Danmarks Fjord, Northeast Greenland. Meddr Grønland 111(7), 24 pp.

Birkenmajer, K. 1978: Ordovician succession in south Spitsbergen. Stud. geol. Pol. 49, 47-82.

Birkenmajer, K. 1981: The geology of Svalbard, the western part of the Barents Shelf and the continental margin of Scandinavia. In Nairn, A. E. M., Churkin, M. \& Stehli, F. G. (edit.) The ocean basins and margins. Vol. 5. The Arctic Ocean, 265-329. New York: Plenum.

Christie, R. L. \& Peel, J. S. 1977: Cambrian-Silurian stratigraphy of Børglum Elv, eastern North Greenland. Rapp. Grønlands geol. Unders. 82, $48 \mathrm{pp}$.

Cowie, J. W. 1961: The Lower Paleozoic geology of Greenland. In Raasch, G. O. (edit.) Geology of the Arctic 1, 160-169. Toronto U. P.

Cowie, J. W. 1971: The Cambrian of the North American Arctic regions. In Holland, C. H. (edit.) Cambrian of the New World, 325-383. London: Wiley Interscience.

Ethington, R. L. \& Clark, D. L. 1971: Lower Ordovician conodonts in North America. Mem. geol. Soc. Am. 127, 185-205.

Ethington, R. L. \& Clark, D. L. 1982: Lower and Middle Ordovician conodonts from the Ibex area, western Millard County, Utah. Geology Stud. Brigham Young Univ. 28(2), 160 pp.

Ethington, R. L. \& Repetski, J. E. 1984: Paleobiogeographic distribution of Early Ordovician conodonts in central and western United States. Spec. Pap. geol. Soc. Am. 196, 89-101.

Fortey, R. A. 1979: The Ordovician of Spitsbergen and its relevance to the base of the Middle Ordovician in North America. Dept geol. Sci. Virginia Poly. Inst. Mem. 2, 33-40.

Fortey, R. A. 1986: Early Ordovician trilobites from the Wandel Valley Formation, eastern North Greenland. Rapp. Grønlands geol. Unders. 132, 15-25.

Fortey, R. A. \& Barnes, C. R. 1977: Early Ordovician conodont and trilobite communities of Spitsbergen: influence on biogeography. Alcheringa 1, 297-309.

Fortey, R. A. \& Bruton, D. L. 1973: Cambrian - Ordovician rocks adjacent to Hinlopenstretet, north Ny Friesland, Spitsbergen. Bull. geol. Soc. Am. 84, 2227-2242.

Fortey, R. A. \& Peel, J. S. 1983: The anomalous bathyurid trilobite Ceratopeltis and its homeomorphs. Spec. Pap. Palaeontology 30, 51-57.

Fränkl, E. 1955: Weitere Beiträge zur Geologie von Kronprins Christians Land (NE-Grönland). Meddr Grønland 103(7), $35 \mathrm{pp.}$

Haller, J. 1971: Geology of the East Greenland Caledonides, 411 pp. New York: Wiley Interscience.

Higgins, A. K., Ineson, J. R., Peel, J. S., Surlyk, F. \& Sønderholm, M. in press: The Franklinian basin in North Greenland. In Trettin, H. P. (edit.) The Innuitian region. The geology of North America E. Ottawa: Geol. Surv. Canada.

Holtedahl, O. 1920a: On the Paleozoic series of Bear Island, especially on the Heclahook System. Norsk geol. Tidsskr. 5, 121-148.

Holtedahl, O. 1920b: Notes on the Ordovician fossils from Bear Island collected during the Swedish expeditions of 1898 and 1899. Norsk geol. Tidsskr. 5, 79-93.

Horn, G. \& Orvin, A. K. 1927: Geology of Bear Island. Skr. Svalbard og Ishavet 15, 152 pp.

Hurst, J. M. 1984: Upper Ordovician and Silurian carbonate shelf stratigraphy, facies and evolution, eastern North Greenland. Bull. Grønlands geol. Unders. 148, 73 pp.

Ineson, J. R. \& Peel, J. S. 1987: Cambrian platform - outer shelf relationships in the Nordenskiöld Fjord region, central North Greenland. Rapp. Grønlands geol. Unders. 133, 13-26.

Ineson, J. R., Peel, J. S. \& Smith, M. P. 1986: The Sjælland Fjelde Formation: a new Ordovician formation from eastern North Greenland. Rapp. Grønlands geol. Unders. 132, 27-37.

Jepsen, H. F. 1971: The Precambrian, Eocambrian and early Palaeozoic stratigraphy of the Jørgen Brønlund Fjord area, Peary Land, North Greenland. Bull. Grønlands geol. Unders. 96, 42 pp. 